OPEN ACCESS

Edited by:

Corwin Sullivan,

University of Alberta, Canada

Reviewed by:

Eline Naomi Van Asperen,

Durham University, United Kingdom

Hugh Gregory McDonald,

Bureau of Land Management,

United States

*Correspondence:

Helena Machado

hbcmachado@hotmail.com

Specialty section:

This article was submitted to

Paleontology,

a section of the journa

Frontiers in Ecology and Evolution

Received: 28 February 2019

Accepted: 05 June 2019

Published: 03 July 2019

Citation:

Machado H and Avilla L (2019) The Diversity of South American Equus:

Did Size Really Matter?

Front. Ecol. Evol. 7:235

doi: 10.3389/fevo.2019.00235

\section{The Diversity of South American Equus: Did Size Really Matter?}

\author{
Helena Machado ${ }^{1,2 *}$ and Leonardo Avilla ${ }^{2}$ \\ ${ }^{1}$ Earth Sciences Department, University of Oregon, Eugene, OR, United States, ${ }^{2}$ Laboratório de Mastozoologia, \\ Departamento de Zoologia, Instituto de Biociências, Universidade Federal do Estado do Rio de Janeiro, Rio de Janeiro, Brazil
}

The extant horse genus Equus originated in North America, probably during the late Miocene/early Pliocene, and its entrance into South America was possibly related to one of the last four stages of the Great American Biotic Interchange. Nonetheless, the genus had a broad geographic distribution throughout South America. Five species of Equus were traditionally recognized on this continent, although recently they have been synonymized into three: Equus neogeus, E. insulatus, and E. andium. However, the diagnoses of the three species are still unclear and a recent study showed that the characters previously used are not taxonomically valid, with the implication that in South America, Equus was represented by a single species, E. neogeus. This contribution is intended to update current knowledge on the diversity of South American Equus. Accordingly, a synthesis of prior knowledge as well as an update on the fossil distribution of Equus is presented here. Dental analyses were carried out, and the results revealed a clear overlap among the currently recognized species. Characters of the autopodia were also reanalyzed with greater sampling, and the results once again confirmed that a single species was present in South America. The update of fossil occurrences increased knowledge of the geographical distribution of the genus in South America. There are records throughout almost the entire continent, except for regions in the Amazonian rain forest, at latitudes south of $40^{\circ} \mathrm{S}$, and at altitudes above 3,000 m. Furthermore, evaluating the new data with reference to geography revealed that $E$. neogeus formed a smooth cline, in which variation was gradual and continuous. It is also inferred that observed phenotypic variation is probably related to topography.

Keywords: Equus, South America, autopodia, paleobiogeography, cline

\section{INTRODUCTION}

The genus Equus originated during the Early-Middle Pliocene in North America, probably in the Blancan North American Land Mammal Age (NALMA), but it was during the Pleistocene that the group reached its widest geographical range, with records on all continents except Antarctica and Australia (MacFadden, 1994; Eisenberg and Redford, 1999; Alberdi and Prado, 2004; Prado and Alberdi, 2017). However, very recently the genus Equus was retricted to its traditional crown-group, which included only the diversity from the early Pleistocene to the Recent (Barron-Ortiz et al., in press). Currently the genus is restricted to Eurasia and Africa, and its extinction in the Americas is probably related to negative selection against the megafauna at the end of the Pleistocene and the beginning of the Holocene (MacFadden, 1994).

The invasion of Equus into South America was possibly related to one of the dispersion events of the Great American Biotic Interchange (GABI) which occurred from the end of Pliocene to the terminal Pleistocene (Webb, 1978; MacFadden, 1994; Woodburne, 2010; Bacon et al., 2016). 
Nonetheless, the genus had a widespread distribution throughout South America and survived into the Late Pleistocene (MacFadden and Azzaroli, 1987; Alberdi and Prado, 2004; Prado and Alberdi, 2017). Traditionally, five species have been recognized on this continent (Prado and Alberdi, 1994; Alberdi and Prado, 2004), but recently the number has been reduced to three: Equus neogeus, E. insulatus, and E. andium (Prado and Alberdi, 2017). However, Machado et al. (2018) suggested the possibility that South America might have had only a single species of native Equus, namely E. neogeus.

The traditional taxonomy of South American Equus has always relied on the length of the autopodium, which was considered to be greatest E. neogeus, smallest in E. andium, and intermediate in E. insulatus (Prado and Alberdi, 2017). Owing to the difficulty of finding taxonomically significant differences in qualitative dental characters, the current taxonomy of South American Equus also relies on tooth proportions (Prado and Alberdi, 1994, 2017; Alberdi and Prado, 2004). However, dental analyses alone have been unable to fully distinguish between the putative species, instead identifying a group with smaller teeth dimensions corresponding to E. andium and a larger group encompassing the other species (Prado and Alberdi, 1994, 2017; Alberdi and Prado, 2004).

No clear, objective and certain basis for distinguishing between the three species has been established and Machado et al. (2018) and Machado (2018) showed that the characters used previously are not taxonomically valid. Furthermore, when a larger dataset is analyzed, there is a great overlap among all three Equus species in morphospace (Machado, 2018; Machado et al., 2018). The most plausible interpretation is that Equus was probably represented in South America by only a single species, E. neogeus. Morphological variation in autopodia, perhaps representing a type of cline, might then be expected.

The aim of this contribution is to critically update current knowledge of the diversity of South American native Equus. An historical background is presented, mainly in order to establish when the paradigm of the importance of size for the taxonomy of South American native Equus was assumed and why it must be forsaken. Additionally, tooth analyses are performed, autopodial characters are reanalyzed with greater sampling and new inferences are drawn.

\section{MATERIALS AND METHODS}

The historical background of South American Equus studies presented here is a compilation from a detailed survey of the literature, beginning with the first record of the genus in South America (Owen, 1840).

The tooth analyses incorporated 1,409 dental specimens of South American Equus, including (lower and upper) molars and premolars at an intermediate wear stage (Solounias and Semprebon, 2002). Dental elements were analyzed both qualitatively and quantitatively, using data acquired with digital calipers with $0.01 \mathrm{~mm}$ precision, following the recommendations of Eisenmann et al. (1988), Figure 1. We relied on photos for information on 144 out of the 1,409 specimens analyzed, and in these cases we followed the procedures of Mariano and Romano (2017) and took measurements using ImageJ (Rasband, 1997).

When dealing with isolated Equus teeth, only the second premolar (P2/p2) and the last molar (M3/m3) are easily identified (Eisenmann et al., 1988). Since most of this sample analysis relied on isolated teeth, upper and lower cheek teeth were divided into three categories: P2/p2; M3/m3; and P3, P4, M1, M2/p3, p4, m1, and $\mathrm{m} 2$.

Bivariate and multivariate analyses were performed. The bivariate analysis was carried out on the tooth measurements that are more related to the dimensions of occlusal surface and was run in Microsoft Excel (2010 version). Multivariate analyses included PCA and CVA, and for the PCA the problem of missing data was handled by the Iterative Imputation method (Hammer, 2012; Machado et al., 2018).

The methodology used in the autopodial analysis took into consideration the latest proposition of Prado and Alberdi (2017) and followed the methods and reasoning of Machado et al. (2018). We analyzed 29 metatarsi (MTIII), 33 metacarpi (MCIII) and 54 first phalanges (IPHIII) of E. andium; 53 MTIII, 47 MCIII, and 70 IPHIII of E. insulatus; and 20 MTIII, 14 MCIII, and 28 IPHIII of E. neogeus. Since the North American E. occidentalis used to be included in the same subgenus as the South American Equus (Hoffstetter, 1950), the northern species was used here as a control group and 32 MTIII, 40 MCIII and 56 IPHIII of E. occidentalis from Rancho La Brea, California were also analyzed.

Comparative morphological, morphometric and statistical analyses were performed, using measurements taken according to the recommendations of Eisenmann et al. (1988, Figure 1) with digital calipers with $0.01 \mathrm{~mm}$ precision.

The bivariate analyses were performed in Microsoft Excel (2010 version), based on the dimensions of the autopodial elements as captured by measurements 1,3 , and 4 of MTIII and MCIII, and measurements 1, 3, and 5 of IPHIII. The PCA and CVA were based on all the measurements recommended by Eisenmann et al. (1988), but measurements 10, 11, 12, and 13 of IPHIII were omitted due to the difficulty of distinguishing between some examples of this bone as being left or right. All analyses were performed in Past version 3.16 (Hammer, 2012).

The statistical analysis consisted of a variance analysis using the non-parametric Kruskal-Wallis test, with Dunn's method as a post-hoc test, and was executed in BioEstat 5 (Ayres et al., 2007). The only measurements used in this analysis were those related to the Gracility Index (Alberdi and Prado, 2004) and to the biomechanical properties of the distal limb bones measurements $1,3,4,5$, and 10 of MTIII and MCIII, and measurements 1, 3, 5, 7, and 8 of IPHIII (Machado et al., 2018).

All the specimens represent adult individuals and are deposited in the paleontological collections of the following institutions: Museu Nacional (MN) and Museu de Ciências Naturais da Pontifícia Universidade Católica de Minas Gerais (MCL), Brazil; Museo Argentino de Ciencias Naturales "Bernardino Rivadavia" (MACN-Pv) and Museo de La Plata (MLP), Argentina; Museo de Historia Natural "Gustavo Orcés V” (V and MECN), Ecuador; Museo Nacional Paleontología y Arquiología de Tarija (TAR), Bolivia; Museo de Historia Natural (UNMSM), Peru; Museo de Ciencias Naturales Federico Carlos 

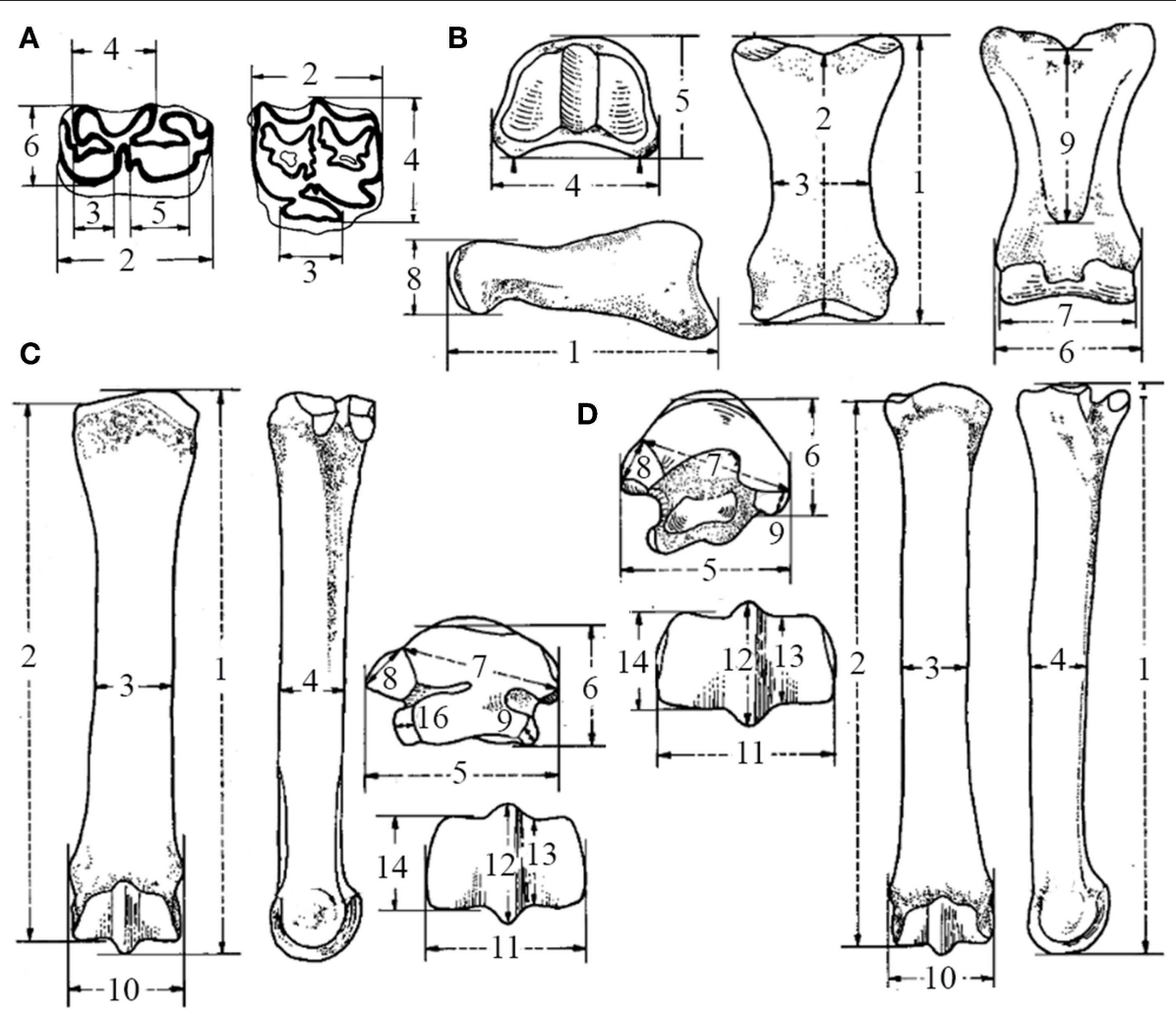

FIGURE 1 | Dimensions used for teeth and autopodial analyses, according to the Hipparion Conference (Modified from Eisenmann et al., 1988): (A) Lower dentition (left) (2) occlusal length, (3) length of the preflexid, (4) length of the double-knot, (5) length of the postflexid, (6) maximal width; upper dentition (right) (2) occlusal length, (3) occlusal length of the protocone, (4) occlusal width; (B) IPHIII (2) anterior length, (3) minimal breadth, (4) proximal breadth, (5) proximal depth, (6) distal breadth at the tuberosities, (7) distal articular breadth, (8) distal articular depth, (9) minimal length of the trigonum phalangis; (C) MCIII and (D) MTIII (2) medial length, (3) minimal breadth, (4) depth of the diaphysis, (5) proximal articular breadth, (6) proximal articular depth, (7) maximal diameter of the articular facet for the third tarsal/carpal, (8) diameter of the articular facet for the fourth tarsal/carpal, (9) diameter of articular facet for the second tarsal/carpal, (10) distal maximal supra-articular breadth, (11) distal maximal articular breadth, (12) distal maximal depth of the keel, (13) distal minimal depth of the lateral condyle, (14) distal minimal depth of the medial condyle, (16) diameter of the posterior facet for the fourth carpal.

Lehman, Colombia; and American Museum of Natural History $(\mathrm{AMNH})$ and La Brea Tar Pits and Museum (previously the George C. Page Museum; GCPM), USA.

An updated tabulation of the distribution of fossil Equus in South America was made through a survey of the literature. Catalog cards from the Museo de La Plata (MLP) and Museo Argentino de Ciencias Naturales "Bernardino Rivadavia" (MACN-Pv) were also consulted as a source of information on localities where Equus fossils have been found, as was the catalog of fossil-types and figures from the paleo vertebrate collection of the Museu Nacional (MN).

\section{RESULTS}

\section{Comments on the State of Knowledge of South American Equus Taxonomy: Did Size Really Matter?}

The urgency of a new taxonomic arrangement for South American Equus becomes clear when its taxonomic history is reviewed. Most of the traditional taxonomy was founded on poor samples and superficial diagnoses, which mainly used differences in size to characterize the various putative species. Thus, most taxonomic revisions of South American Equus neglected the fact that morphological variations can reflect non-taxonomic factors, such as ontogeny, sexual dimorphism and individual/population differences, and particularly adaptation driven by exposure to different environments (lowlands vs. highlands and within distinct altitudes in the Andes). However, the taxonomic zeitgeist of the mid-nineteenth to mid-twentieth century favored splitting, which generated many poorly diagnosed species and resulted in a distorted view of ancient diversity. South American native Equus taxonomy conformed to this pattern.

The history of the taxonomy of native fossil horses in South America could not have had a more special beginning than at the hands of one of the greatest scientists of all time, Charles Darwin. The survey expedition of the HMS Beagle brought Darwin to the Province of Santa Fé, Central-Eastern Argentina, where he found a horse molar at the locality of Bajada de Santa Fé in October 1833 (Figure 2A; Lister, 2018). 


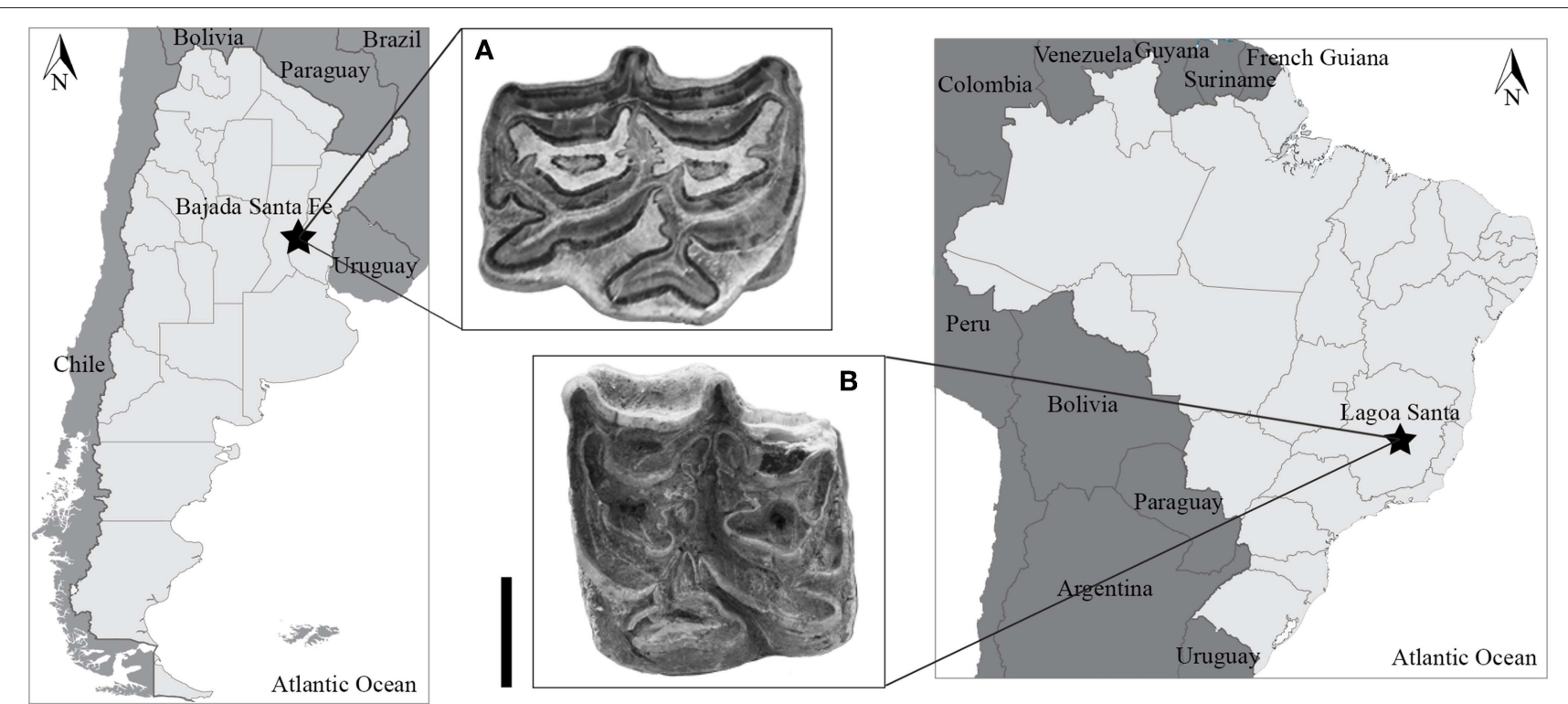

FIGURE 2 | Molars associated with the first records of Equus from South America: (A) right M2 collected by Darwin in Entre Ríos, Santa Fé (Argentina) and identified by Owen; (B) left M1 found in association with the holotype of E. neogeus in Lagoa Santa, Minas Gerais (Brazil) and used in the original description by Lund. Scale $1 \mathrm{~cm}$.

Although other South American Holarctic mammals, such as proboscidean gomphotheres (Cuvier, 1806), had previously been found and published, Darwin was surprised to find a horse tooth in Argentina, and at first he thought it might be the remains of a domestic animal (Lister, 2018). After careful examination, however, he was left with no doubt that it was from a fossil horse, because he had collected it from a layer that also contained other native extinct mammals (Lister, 2018). This molar is believed to be the first fossil evidence of native horses in South America and is housed in the Natural History Museum in London (England). The fossils collected by the Beagle expedition were studied and first described by Richard Owen in 1838, and he considered the aforementioned horse molar to be essentially similar to those of living (domestic) horses, identifying it only as "a species of horse" (Lister, 2018; Figure 2A). Subsequently, Owen (1845) revisited the fossil molar and considered it to represent a new species, which was named Equus curvidens.

At the same time (between 1835 and 1845), the Danish explorer Peter W. Lund collected plants, animals and fossils in the region of Lagoa Santa in the State of Minas Gerais, southeastern Brazil. Lagoa Santa includes a very important Brazilian speleological province with hundreds of caves, from which numerous human and megafaunal fossils were recovered. Among these, a metacarpal fossil bone of a native horse was recognized as a previously unknown species by Lund (1840) and was named E. neogeus (Figure 2B). Although Lund misspelled its specific epithet (the correct orthography would have been "neogaeus," a Greek word meaning "new world"), the original spelling Equus neogeus must be maintained according to the International Code of Zoological Nomenclature. Later, Lund (1846) presented a list of species found in several caves at Lagoa Santa, in which the horse metacarpal appeared as Equus aff. caballo (probably a misspelling of Equus caballus). However, the use of this designation left open the interpretation that Lund might have been in doubt about the taxonomic validity of Equus neogeus. Additionally, this manuscript was among the first sources to mention the association of human and megafaunal fossils in South America, suggesting that both might have coexisted (Lund, 1846; Owen, 1869). Furthermore, Peter W. Lund left a manuscript indicating the existence of at least two more new species of Equus (E. escrivanensis and E. soarensis) from the Lagoa Santa caves, which were later described by Winge (1906). However, the specimens clearly represent the same species Equus neogeus, as noted in subsequent authors' revisions (Hoffstetter, 1950).

The French explorer Hugues A. Weddell collected and described several fossil mammals from the Tarija deposits of southern Bolivia (1845-1846; Weddel, 1851). Among those, he named an indigenous horse Equus macrognathus, diagnosed by a large-sized mandible. It should be noted that this author also pointed out the great resemblance of E. macrognathus, especially with regard to its large size, to the lowland Pampean fossil horse E. curvidens described by Owen (1845). Although most authors have indicated that Equus from the lowlands of South America (Argentina, Uruguay, and Brazil, including the Pampean region) are larger than those from Tarija (Hoffstetter, 1950; MacFadden and Azzaroli, 1987; Alberdi and Prado, 1992; Prado and Alberdi, 2017), direct comparisons of a large sample of specimens do not uphold this argument, and Machado et al. (2018) found no statistical support for a size difference in an analysis of autopodial bones of South American Equus from several localities representing its paleo geographical range (from the lowlands to the highlands of the Andes). 
One of the most important studies of South American Equus taxonomy is that of Gervais (1855). This author argued that E. macrognathus from Andean Bolivia and E. americanus, E. curvidens, and E. neogeus from the lowlands of Chile, Argentina and Brazil must all represent the same species and should be synonymized by priority under the name E. neogeus. This is the first time that South American highland and lowland Equus were considered to belong to a single species, an argument defended by Machado (2018).

The first taxonomic comparisons among South, Central and North American Equus species were made by Owen (1869). In contrast to his French colleague, the British scientist argued that most known fossils of Equus recognized at that time (E. neogeus, E. curvidens, E. conversidens, E. tau, E. macrognathus, and E. devillei) represented valid, distinct species. However, most of these Equus species had been described by Owen himself, and his taxonomic contributions are known to have been underpinned by a taxonomic splitter approach. Accordingly, it is clear that the author's only intention was to identify morphological attributes that could distinguish (Lund's, 1840) E. neogeus from his own E. curvidens (Owen, 1845), given that Lund's name would have taxonomic priority if the two proved synonymous. However, it took more than 100 years before $E$. curvidens was formally recognized as a junior synonym of $E$. neogeus (Souza Cunha, 1971).

The second half of the nineteenth century witnessed paleontological explorations in South America that extended to the highest altitudes of the Andes. Wagner (1860) was the first to publish on a native Equus found on the Antiplano around Quito, Ecuador, which he recognized as a new species, Equus fossilis andium. Later, Branco (1883) proposed the new combination Equus andium for the fossils studied by Wagner (1860) and described several other specimens of Equus andium from diverse fossiliferous deposits in the Ecuadorian Andes.

During the second half of the nineteenth century and the beginning of the twentieth, several other new species of Equus were named from South America (e.g., E. lundii Boas, 1881, E. argentinus Burmeister, 1875, E. quitensis Wolf, 1875 and E. rectidens Gervais and Ameghino, 1880, E. muñizi Ameghino, 1904, E. gracilis, Ameghino, 1904, E. insulatus Ameghino, 1904, and E. haasei Reche, 1905), but this may be explained by the fact that taxonomy all around the world was dominated by a splitter approach. However, those species were very often poorly diagnosed (and sometimes lacked any diagnosis at all) and defined based only on variations in tooth morphology. Furthermore, there was a tendency among natural historians of the time to consider all morphological variations as valid taxonomic diagnostic features, neglecting that such variations can also result from ontogeny, dimorphism, and individual/population differences. In the particular case of horse teeth, many variations can arise through masticatory wear (Gromova, 1949, 1952).

As a result, most subsequent taxonomic studies on South American Equus were revisions of dental diagnoses of the diverse nominal species recognized in previous papers (Sefve, 1912; Boule and Thevenin, 1920; Hoffstetter, 1950, 1952; Souza Cunha, 1971; MacFadden and Azzaroli, 1987; Alberdi and Prado, 1992;
Prado and Alberdi, 2017; Machado, 2018). Boule and Thevenin (1920) started their revision paper by arguing that: “... molars of horses are quite variable; and, because we did not sufficiently take into account this variability, we have multiplied to excess the names of fossil horse species." Based on this argument, these authors conducted a detailed morphological analysis, mainly considering dental features, of a very abundant sample of Equus from Tarija (Bolivia), named E. insulatus after Ameghino (1904). Thus, they demonstrated that E. insulatus is part of an extensive but expected range of morphological variation seen in E. andium (i.e., they considered the Equus from Tarija to be $E$. andium Branco, race insulatus Ameghino). Further, these authors reinforced their previous argument by saying: "There is, between the E. andium of Bolivia and the one that lived at a higher altitude in Ecuador, a similar size difference as exists between the extant (domestic) horses of the plain and those living in the highlands of Bolivia." Again, it was demonstrated that size distinctions within South American Equus from different altitudes were expected morphological variations of a single species with a wide geographic range. However, and unfortunately, most subsequent authors did not pay attention to these important arguments.

Spillman (1938) took the opposite perspective in conducting his taxonomic revision of Ecuadorian Equus. First, he applied the genus name Neohippus to these specimens (Abel, 1913), instead of Equus, without any justification. According to Hoffstetter (1950), the genus Neohippus must be considered a nomen nudum, because its original description neither includes a diagnosis, nor designates a genotype. Furthermore, Hoffstetter (1950) argued that Neohippus was a synonym of Equus, with the latter having taxonomic priority. However, the species of Spillman (1938) will be cited below under their original names (i.e., using the genus Neohippus) for historical reasons. Spillman (1938) recognized a diversity of five species, four of which were previously unknown. He recognized and diagnosed each of the species using chronostratigraphy and/or endemism (localities and altitudes) together with dental and post-cranial morphology. In this scheme, the following fossil horses would be present in Ecuador, from earliest to the most recent: Neohippus andium, the horse of the ancient Ice Age of Ecuador; N. martinei n. sp., the interglacial horse from the highlands of Ecuador; N. santaeelenae n. sp., the interglacial horse from the coastal region of Ecuador; $N$. rivadeneirae $\mathrm{n}$. sp., the horse of the second or last main Ice Age (Last Glacial Maximum, LGM); and N. postremus n. sp., the post-glacial horse of Ecuador from prehistoric deposits. However, it is clear that this author did not consider the stages of tooth wear, leading to excessive taxonomic splitting, even though most of the morphological diagnoses for his new species are based on differences in dental crown morphology. Furthermore, Spillman (1938) was the first taxonomist to diagnose species of South American Equus using proportions and sizes of bones, a tendency seen in taxonomic treatments of the group over the following 80 years (Porta, 1960; MacFadden and Azzaroli, 1987; Alberdi and Prado, 1992; Prado and Alberdi, 2017). However, morphological variations would be expected to occur among animal populations that inhabited different environments, and in particular might have been driven by an altitudinal gradient (Avilla et al., 2018; Machado et al., 2018). 
One of the most well-known taxonomic reviews for South American Equus was that by Hoffstetter (1950), mainly because it initiated a period of taxonomic stability lasting more than 60 years. One of the goals of Hoffstetter (1950) was to establish the genus Amerhippus, diagnosed by a single feature: the lack of an infundibulum in the lower incisors. This proposed genus was the result of dental comparisons between the extant $E$. caballus and the species recorded in the Pleistocene of Ecuador, $E$. andium from the highlands and E. santaeelenae from the lowlands (Hoffstetter, 1950). On a later and admittedly brief trip to South America, specifically to Bolivia and Argentina, Hoffstetter (1950) also recognized the lack of an infundibulum in both E. insulatus from the highlands and E. curvidens from the lowlands. The remaining South American species were analyzed according to the literature available at that time, and the lack of an infundibulum in their lower incisors was also noticeable (Hoffstetter, 1950). Therefore, Amerhippus was considered to include all South American Equus valid at that time, namely Amerhippus andium, A. insulatus, A. martinei, A. curvidens, $A$. santaeelenae, and $A$. neogeus, in addition to the North American Equus occidentalis from the La Brea Tar Pits, California (USA) (Hoffstetter, 1950). However, Hoffstetter (1950) did not mention or justify the exclusion of Neohippus (=Equus) rivadeneirae and $N$. postremus, species named by Spillman (1938), and no other study after this revision made any mention of either species. Under the taxonomy proposed by Hoffstetter (1950), the first three Amerhippus species listed above are, small, medium-sized and large Andean native horses, respectively, whereas the last three are very large lowland ones. However, Hoffstetter (1950) did not explicitly use size differences to distinguish among these species or provide any additional characters to diagnose those species. All revisions or taxonomic propositions after Hoffstetter (1950) followed this size-based taxonomic framework, which is why this contribution is so important for South American native Equus taxonomy. Moreover, Hoffstetter (1950) considered A. andium to be the type genus of Amerhippus since it was the best-known species of the putative genus at the time and was easily identifiable due to its reduced size. However, this same author in a latter monograph (Hoffstetter, 1952) proposed that Amerhippus was a subgenus of Equus, and most succeeding contributions followed this taxonomic rearrangement (MacFadden and Azzaroli, 1987; Alberdi and Prado, 2004; Prado and Alberdi, 2017; Machado et al., 2018).

In 1960, Porta studied the fossil horses from Bogotá (Colombia) and produced the first detailed description of a cranium of E. lasallei, a species that had been briefly described and named by Daniel (1948). However, one of the most important pieces of information overlooked in revisions of South American Equus until the work of Porta (1960) was not the taxonomic validity of $E$. lasallei, but the presence of two large-sized Equus that inhabited the Andes during the Pleistocene (specimens referred to E. lasallei and E martinei). Thus, at that moment, four size-based native horse species were recognized in the Andes: the small E. andium, the medium-sized E. insulatus and the very large E. lasallei and E. martinei.
Souza Cunha (1971) analyzed the holotypes of E. neogeus and E. curvidens, as well as several specimens assigned to each of these species, which collectively represented the first fossil horses discovered in South America. Souza Cunha (1971) also described for the first time the fossils of E. neogeus collected by Lund in Lagoa Santa, Minas Gerais (Brazil), which until then had been mentioned only briefly in the literature. However, the greatest contribution of Souza Cunha (1971) was to propose E. neogeus as a senior synonym of E. curvidens by priority. For the first time, all Cis-Andean (the area east of Andes) lowland native Equus were grouped under a single name, E. neogeus, leaving E. santaeelenae as the only lowland Trans-Andean native horse.

MacFadden and Azzaroli (1987) described the first skull of E. insulatus, a species that until then was known mainly from isolated teeth, post-cranial bones, and some tooth-bearing maxillae and fragmented mandibles. The authors reviewed E. insulatus and suggested it represented a "morphological intermediate" between the large E. lasallei and the small E. andium. Once more, size was used to define Andean native horse species. However, neither this contribution nor any subsequent taxonomic revision (Alberdi and Prado, 1992; Prado and Alberdi, 2017) made any comments (in either opposition or defense) on the arguments offered by Gervais (1855) and Boule and Thevenin (1920) in their studies of the Tarija horses, which insightfully discussed the validity of E. insulatus and proposed that this taxon might fall within the range of morphological variation expected in E. andium. Furthermore, MacFadden and Azzaroli (1987) assumed the validity of E. insulatus based on the features of a single skull and a few other specimens, disregarding the range of morphological variation pointed out by Gervais (1855) and Boule and Thevenin (1920). The classification of South American Equus recognized by MacFadden and Azzaroli (1987) is very similar to that proposed by Hoffstetter (1950, 1952), except for the inclusion of E. lasallei (Porta, 1960). However, MacFadden and Azzaroli (1987) appeared to ignore the study of Souza Cunha (1971) published 16 years before and considered E. curvidens valid without offering reasons for this judgment.

The revision by Alberdi and Prado (1992) once more used size to distinguish between South American Equus species but differed from previous studies in that quantitative and statistical analyses were used to determine how informative size was for this purpose. Their results supported a similar taxonomy to that proposed by MacFadden and Azzaroli (1987), combined with the synonymy proposition of Souza Cunha (1971). Accordingly, the taxonomy of South American Equus proposed by Alberdi and Prado (1992) included the following five species: E. neogeus, E. andium, E. santaeelenae, E. insulatus and E lasallei. However, Alberdi and Prado (1992) did not explain the exclusion of Equus martinei from their study (Spillman, 1938). There is a large sample of autopodia of Equus martinei in the collection of the Museo de Historia Natural in Quito, Ecuador, and it would have been helpful to include this species, the only large native horse that inhabited the highest Andean areas, in the quantitative analyses. The other large Andean Equus species, E. lasallei, was excluded from Alberdi and Prado's (1992) analyses due to a lack of preserved autopodia. Accordingly, 
their study and taxonomic proposals were biased in that the only large native horse to be analyzed was the lowland $E$. neogeus. During the following 12 years the literature on South American Equus, mostly published by Alberdi and Prado (1992, 1995, 2004); Prado and Alberdi (1994), contained no new taxonomic proposals. However, these publications did produce some taxonomic stability and a degree of consensus in how South American Equus species could be differentiated by their size and proportions, as follows: (1) Equus andium is characterized by the shortest and more robust extremities, with autopodials slightly more pronounced in length and robustness than in $E$. insulatus; (2) E. insulatus has a bigger skull than E. andium, but the two species are morphologically similar, and post-cranial skeletal features indicate that $E$. insulatus is an intermediate form between E. andium and E. neogeus; (3) E. santaeelenae has a larger post-cranial skeleton than $E$. andium, phalanges that are similar in size to those of $E$. neogeus but slightly more robust than $E$. neogeus, and a metatarsus that more closely resembles that of E. insulatus; (4) E. neogeus has larger autopodials than the others, and a dental morphology distinct from that of $E$. santaeelenae; and (5) E. lasallei is also large, but is similar in dental morphology to E. neogeus. In most cases, however, these criteria could not be successfully applied, because when a great sample of specimens was analyzed, there was a clear pattern of overlap between the species (Alberdi and Frassineti, 2000; Machado et al., 2018). In a revision of Chilean native horse fossils by Alberdi and Frassineti (2000), for example, only two specimens of Equus could be identified at specific level, both
A
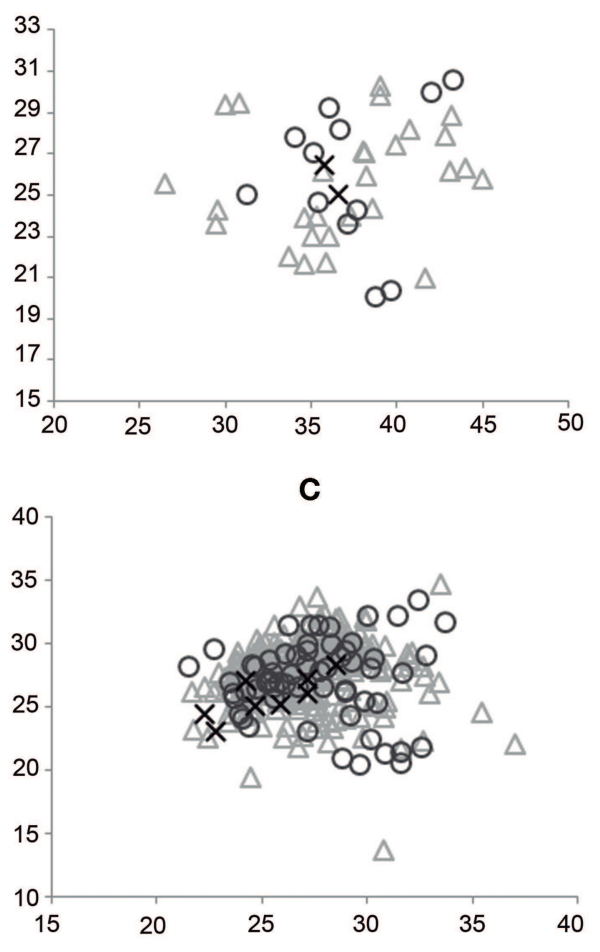

E

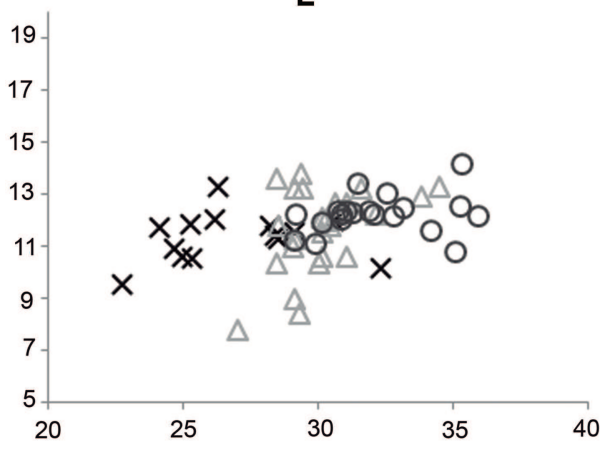

B
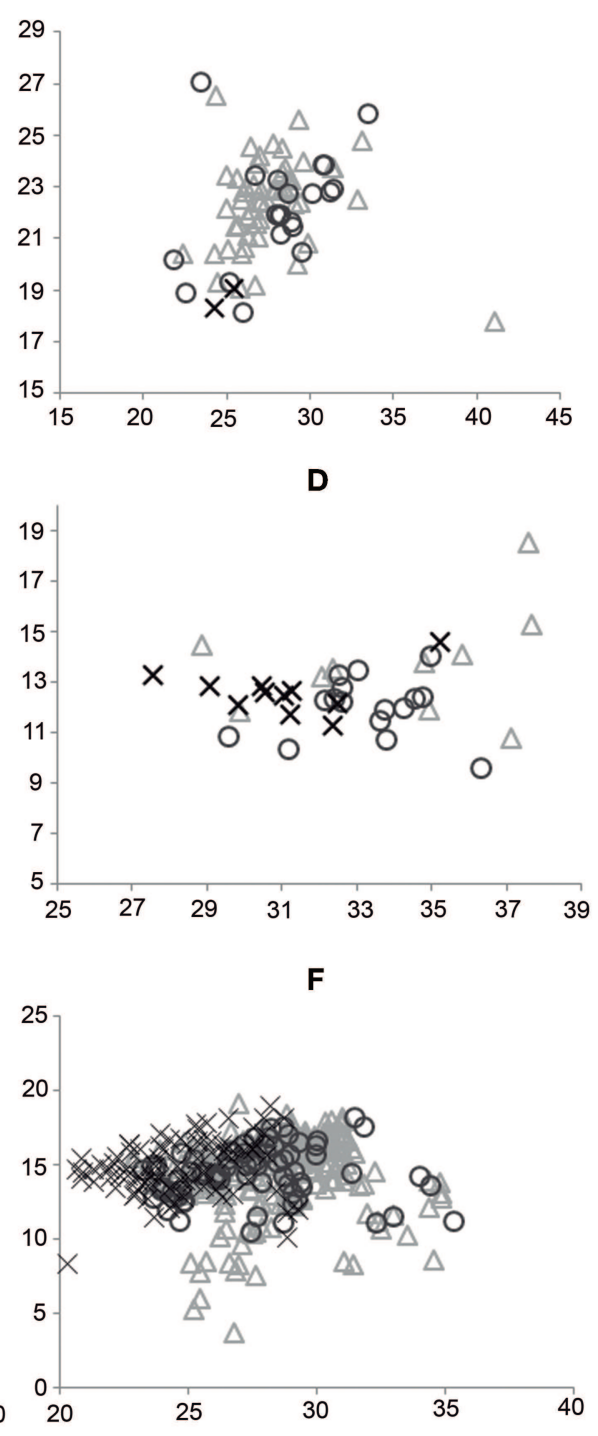

FIGURE 3 | Bivariate analysis of dimensions 2 vs. 4 of P2 (A), M3 (B), and P3, P4, M1, and M2 (C), and dimensions 2 vs. 6 of p2 (D), m3 (E), and p3, p4, m1, and $\mathrm{m} 2$ (F) for E. neogeus (circle), E. insulatus (triangle), and E. andium (x). 
proving to be E. andium. All other specimens were identified only as Equus sp. since their dimensions placed them in an area of overlap among the ranges of size variation seen in E. santaeelenae, E. insulatus, and E. andium.

However, one of Alberdi and Prado's collaborative published works did not follow the taxonomic arrangement of Alberdi and Prado (1992) and was also one of the first molecular (ancient DNA) studies to be carried out on South American native horses (Orlando et al., 2008). This study demonstrated that sequences from South American Equus fossils fell within the caballine horse cluster with maximum bootstrap support, and also cast doubt on the previously accepted taxonomic status of Equus (Amerhippus) as a distinct lineage of horses. Thus, this study left the taxonomy of South American native Equus open to at least two interpretations: (1) all American native horses belonged to a single species, possibly Equus caballus; or (2) South American native horses were a diverse paraphyletic lineage clustered within the total diversity of American species of Equus. The first hypothesis has been winning defenders among researchers of American native horses, and the 2010s have witnessed a change in the dominant taxonomic paradigm, in that even the most traditional authors have recognized that the diversity of South
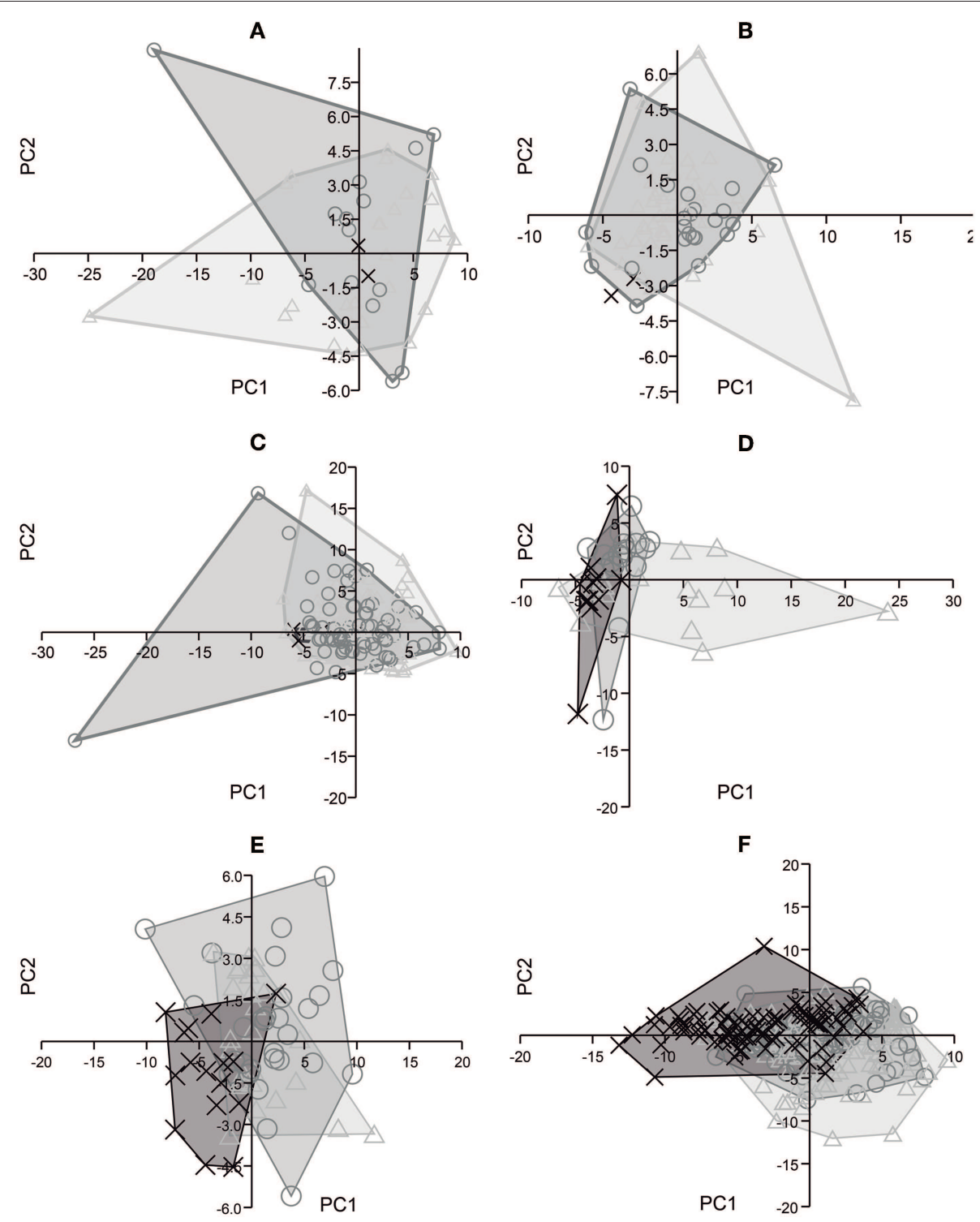

FIGURE 4 | Principal component analysis based on three dimensions of upper cheek teeth and five dimensions of lower cheek teeth of $E$. neogeus (circle), $E$. insulatus (triangle), and E. andium (X). Projected scores on: (A) Principal Components 1 (74\%) and 2 (18\%) from the analysis of P2; (B) Principal Components 1 (59\%) and 2 (29\%) from the analysis of M3; (C) Principal Components 1 (47\%) and 2 (41\%) from the analysis of P3, P4, M1, and M2; (D) Principal Components 1 (57\%) and 2 (31\%) from the analysis of p2; (E) Principal Components 1 (67\%) and 2 (20\%) from the analysis of m3; and (F) Principal Components 1 (61\%) and 2 (25\%) from the analysis of p3, p4, m1, and m2. 
American native horses is smaller than previously proposed (Prado and Alberdi, 2017; Machado et al., 2018).

Consequently, Machado (2014) conducted a morphological comparative analysis of the distal appendicular skeleton of South American Equus, and two groups were recognized: an Andean one, composed of E. andium and E. insulatus and with shorter and more gracile metapodials; and another represented by the lowland species E. neogeus and E. santaeelenae, with longer and more robust metapodials.

Two taxonomic publications appeared in 2017, with contrasting proposals (Prado and Alberdi, 2017; Machado et al., 2018). The first is a reiteration of previous proposals, in which Prado and Alberdi (2017) questioned the validity of the subgenus Equus (Amerhippus) and considered the species E. santaeelenae and E. lasallei to be junior synonyms of $E$. insulatus and E. neogeus, respectively. Only three species of native South American Equus would then be valid: E. andium, E. insulatus and E. neogeus. However, the diagnoses offered for those species were still the same as in Alberdi and Prado (1992), which established that E. insulatus is an intermediate-sized species between the large E. neogeus and the small E. andium. The Prado and Alberdi (2017) study thus upheld the status quo of the last eight decades, at least since Spillman (1938).
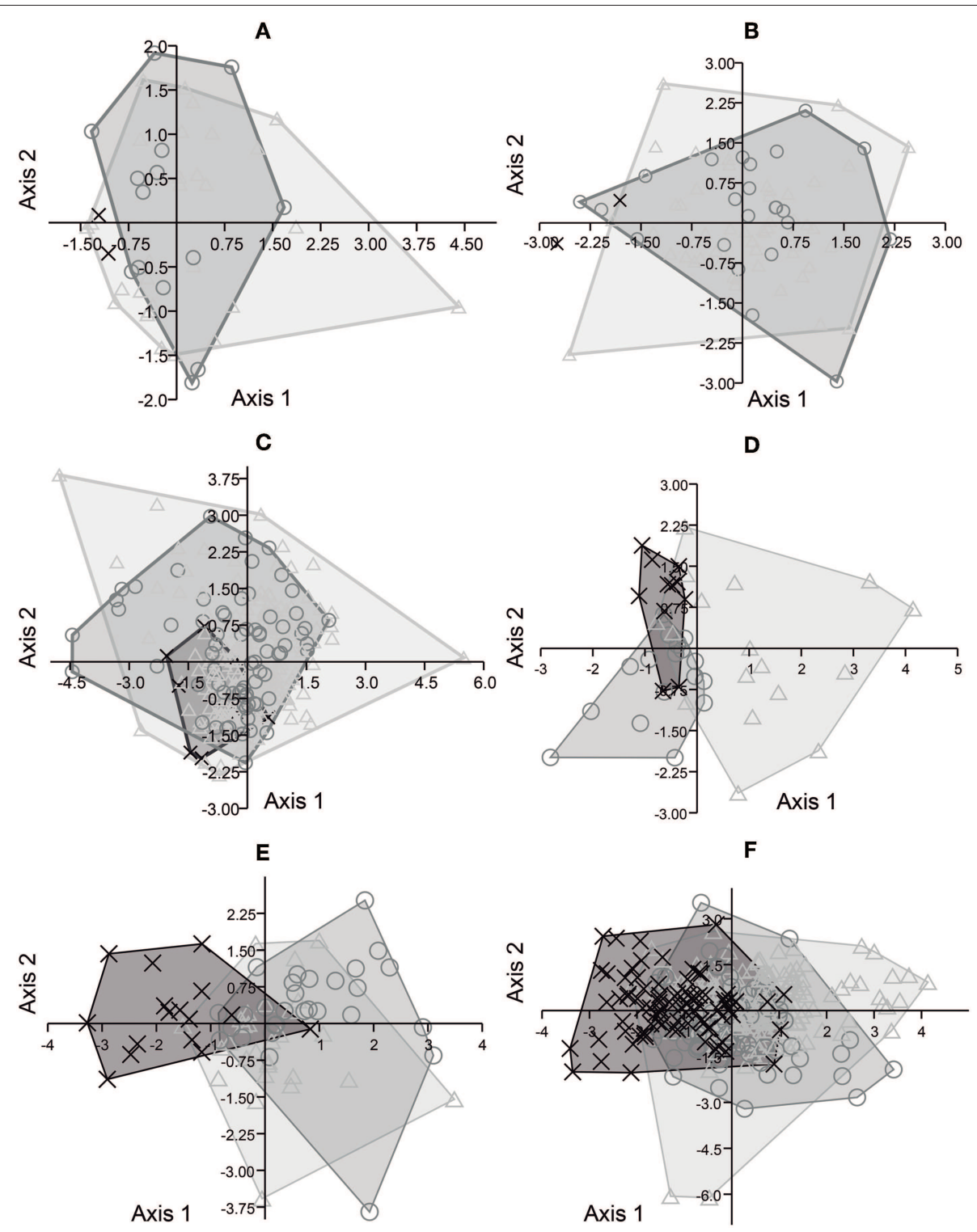

FIGURE 5 | Scatter plots from Canonical Variates Analysis based on three dimensions of upper cheek teeth of $E$. neogeus (circle), E. insulatus (triangle), and $E$. andium (X). Projected scores on: (A) axes 1 (93\%) and 2 (7\%) from the analysis of P2; (B) axes 1 (88\%) and 2 (12\%) from the analysis of M3; (C) axes 1 (71\%) and 2 (29\%) from the analysis of P3, P4, M1, and M2; (D) axes 1 (70\%) and 2 (30\%) from the analysis of p2; (E) axes 1 (90\%) and 2 (10\%) from the analysis of m3; and (F) axes $1(86 \%)$ and 2 (14\%) from the analysis of $\mathrm{p} 3, \mathrm{p} 4, \mathrm{~m} 1$, and $\mathrm{m} 2$. 
On the other hand, Machado et al. (2018) put forward a novel proposal and evaluated the taxonomic importance of the autopodials of South American native Equus, which traditionally were often used to diagnose species within this group as noted above. The results revealed that autopodial features previously used were inadequate for taxonomic purposes, since they failed to distinguish among any of the species of South American native Equus. In fact, the pattern recognized for all autopodial dimensions was a clear, overlapping continuum, revealing a linear variation gradient. The authors proposed that South American Equus might display a clinal variation in which E. andium and E. neogeus would represent the phenotypic extremes of a spectrum from small to large size, while the other species would represent intermediates. Accordingly, size (at least in the way it was traditionally used, described above) cannot distinguish between putative species within South American native Equus. This group might comprise a single species, E. neogeus, characterized by a wide spectrum of clinal morphological variation.

\section{Teeth Analysis}

Bivariate analysis (Figure 3) of dimensions 2 and 4 of the upper cheek teeth, and dimensions 2 and 6 of the lower cheek teeth, showed a complete overlap and superimposition of all specimens of Equus included here.

The PCA analyses (Figure 4) were unable to distinguish between the traditionally recognized five (Alberdi and Prado, 1992), or even the more recently posited three (Prado and Alberdi, 2017), species of South American Equus. Among the upper dentition analyses, that for P2 (Figure 4A) indicated
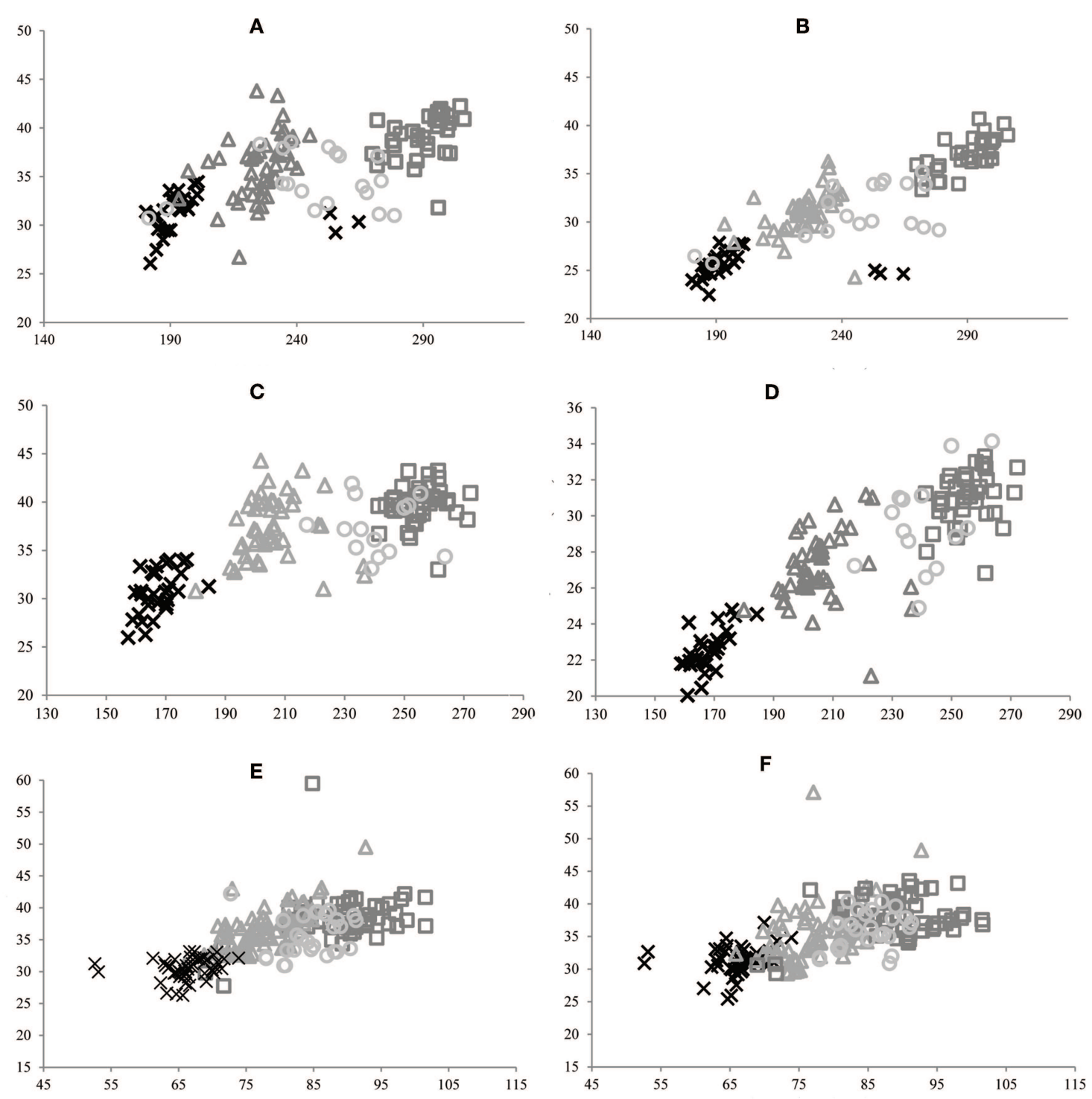

FIGURE 6 | Bivariate analysis of dimensions 1 vs. 3 (A) and 1 vs. 4 (B) of MTIII, dimensions 1 vs. 3 (C) and 1 vs. 4 (D) of MCIII, and dimensions 1 vs. 3 (E) and 1 vs. 5 (F) of IPHIII for E. andium (x), E. insulatus (triangle), E. neogeus (circle), and E. occidentalis (box). 

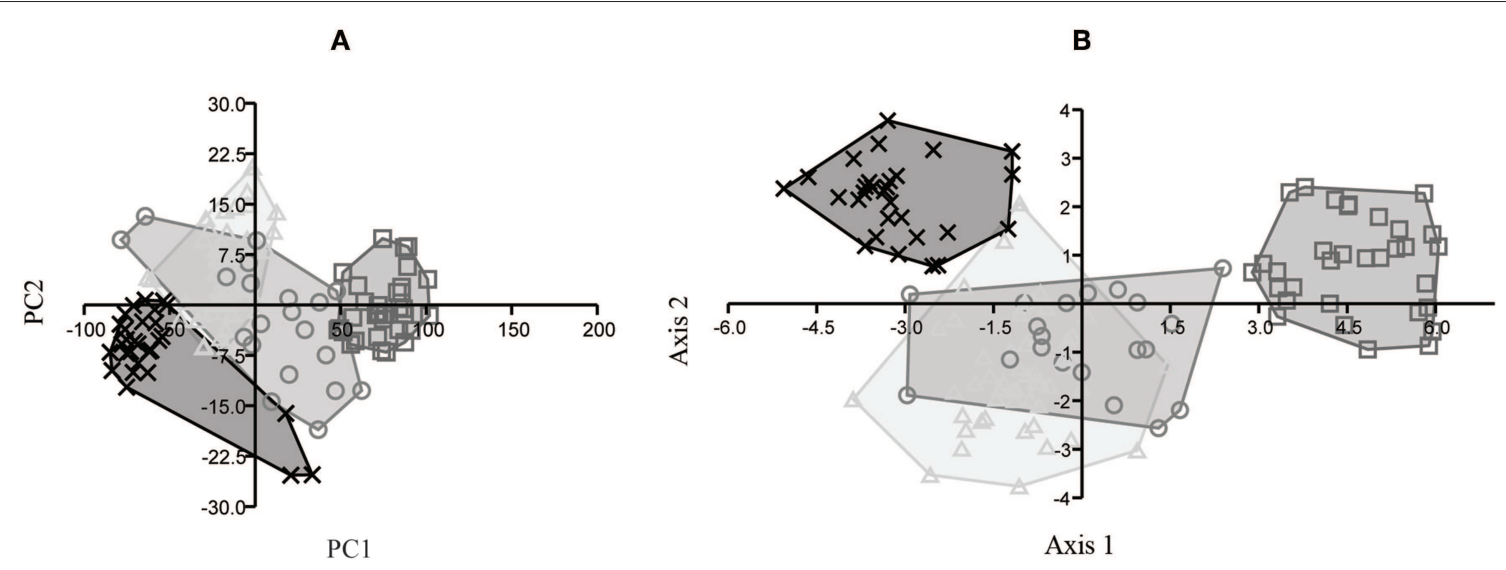

FIGURE 7 | MTIII analysis for E. andium (x), E. insulatus (triangle), E. neogeus (circle), and E. occidentalis (box): (A) projected scores from PCA, PC1 (96\%) and PC2 (2\%); (B) dispersal graph from CVA, axis $1(77 \%)$ and axis $2(20 \%)$.

that PC1 was responsible for $74 \%$, and PC2 for $18 \%$, of the variation. Dimensions 2 and 4 had the most significant effects on PC1 and PC2, respectively. In the analysis of M3 (Figure 4B), PC1 was responsible for 59\% of the variation, and PC2 for 29\%. Dimensions 1 and 4 had the most significant effects on PC1 and PC2, respectively. In the analysis of P3, P4, M1, and M2 (Figure 4C), PC1 was responsible for $47 \%$ of the variation and PC2 for $41 \%$, and dimensions 2 and 4 had the most significant effects on both PC1 and PC2.

Among the lower dentition analyses, that for p2 (Figure 4D) indicated that PC1 was responsible for $57 \%$ of the variation and PC2 for 31\%. Dimensions 2 and 3 had the most significant effects on PC1, while dimensions 4 and 5 had the most significant effects on PC2. In the analysis of $\mathrm{m} 3$ (Figure 4E), PC1 was responsible for $67 \%$ of the variation, and PC2 for $20 \%$. Dimension 2 and dimension 5 had the most significant effects on $\mathrm{PC} 1$ and $\mathrm{PC} 2$, respectively. In the analysis of $\mathrm{p} 3, \mathrm{p} 4, \mathrm{~m} 1$ and $\mathrm{m} 2$ (Figure 4F), PC1 was responsible for $61 \%$ of the variation and PC2 for 25\%. Dimensions 2 and 5 had the most significant effects on PC1, and dimension 6 had the most significant effect on PC2.

The CVA of P2 (Figure 5A) revealed that axis 1 was responsible for $93 \%$ of the variation, and axis 2 for $7 \%$. For M3 (Figure 5B), axis 1 was responsible for $88 \%$ of the variation, and axis 2 for $12 \%$. In the analysis of P3, P4, M1, and M2 (Figure 5C), axis 1 was responsible for $71 \%$ of the variation. Among the lower dentition analyses, CVA for p2 (Figure 5D) revealed that axis 1 was responsible for $70 \%$, and axis 2 for 30\%, of the variation. For $\mathrm{m} 3$ (Figure 5E), axis 1 was responsible for $90 \%$ of the variation, and axis 2 for $10 \%$. The analysis of $\mathrm{p} 3, \mathrm{p} 4, \mathrm{~m} 1$, and $\mathrm{m} 2$ (Figure 5F) revealed that axis 1 was responsible for $86 \%$ of the variation and axis 2 for $14 \%$.

All the CVA analyses (Figure 5) revealed an overlap among all putative species of South American Equus, especially regarding axis 1 , and recognized only a single group.

\section{Autopodia Analysis}

The bivariate analysis took into consideration the relationships between dimensions 1 and 3 and between dimensions 1 and 4 of MTIII and MCIII, and the relationships between dimensions 1 and 3 and between dimensions 1 and 5 of IPHIII, in the putative species E. andium, E. insulatus, E. neogeus, and E. occidentalis. The results obtained do not allow the species to be distinguished from one another: there is clear overlap among the clusters of points representing the various species, revealing a continuum of gradual linear variation (Figure 6).

In the PCA portion of the MTIII analysis (Figure 7A), PC1 was responsible for $96 \%$ of the variation, with dimensions 1 and 2 as the most significant ones, while PC2 was responsible for $2 \%$ of the variation with dimensions 5,6 , and 10 as the most significant variables. In the CVA portion (Figure $7 \mathbf{B}$ ), axis 1 was responsible for $77 \%$ of the variation and axis 2 for $20 \%$.

The Kruskal-Wallis analyses performed on MTIII (Table 1) presented significant values in comparisons of all dimensions between $E$. andium and E. insulatus; between E. andium and $E$. neogeus; between E. andium and E. occidentalis; between $E$. insulatus and E. occidentalis; and between E. neogeus and E. occidentalis. All other comparisons resulted in nonsignificant values.

In the PCA portion of the MCIII analysis (Figure 8A), PC1 was responsible for $96 \%$ of the variation, with dimensions 1 and 2 as the most significant ones, and PC2 for 1\%, with dimensions 3,5 , and 10 as most significant. In the CVA portion (Figure 8B), axis 1 was responsible for $91 \%$ of the variation and axis 2 for $5 \%$.

The results of the Kruskal-Wallis analysis performed on MCIII (Table 2) revealed significant values in comparisons of all dimensions between $E$. andium and E. insulatus; between $E$. andium and E. neogeus; between E. andium and E. occidentalis; and between E. insulatus and E. occidentalis. In comparisons involving dimension 1 a significant difference was also found between E. insulatus and E. neogeus. All other comparisons resulted in non-significant values. 
TABLE 1 | Kruskal-Wallis test results for comparative analysis of MTIII.

\begin{tabular}{lllll}
\hline & $\mathbf{1}$ & $\mathbf{3}$ & $\mathbf{4}$ & $\mathbf{5}$ \\
\hline E. andium vs. E. insulatus & $p<0.05$ & $p<0.05$ & $p<0.05$ & $p<0.05$ \\
E. andium vs. E. neogeus & $p<0.05$ & $p<0.05$ & $p<0.05$ & $p<0.05$ \\
E. andium vs. E. occidentalis & $p<0.05$ & $p<0.05$ & $p<0.05$ & $p<0.05$ \\
E. insulatus vs. E. neogeus & $\mathrm{ns}$ & $\mathrm{ns}$ & $\mathrm{ns}$ & $\mathrm{n}$ \\
E. insulatus vs. E. occidentalis & $p<0.05$ & $p<0.05$ & $p<0.05$ & $p<0.05$ \\
E. neogeus vs. E. occidentalis & $p<0.05$ & $p<0.05$ & $p<0.05$ & $p<0.05$ \\
\hline
\end{tabular}

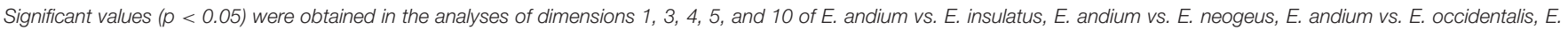
insulatus vs. E. occidentalis, and E. neogeus vs. E. occidentalis; non-significant values were found for all other analyses.

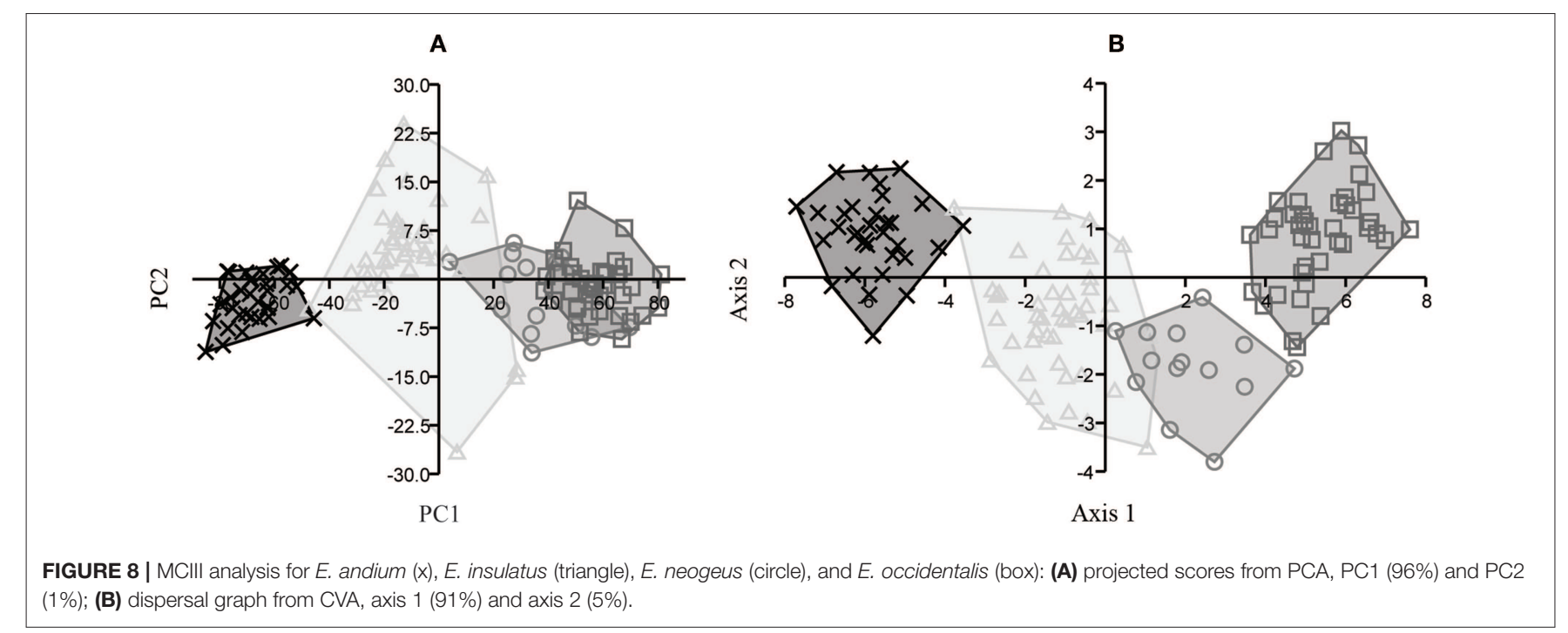

In the PCA portion of the IPHIII analysis (Figure 9A), PC1 was responsible for $82 \%$ of the variation, with dimensions 1 and 2 as the most significant ones, while PC2 was responsible for 7\% of the variation with dimensions 2 and 4 as most significant. The CVA (Figure 9B) revealed axis 1 to be responsible for $90 \%$ of the variation, and axis 2 to be responsible for $5 \%$.

The results of the Kruskal-Wallis analysis of IPHIII (Table 3) revealed significant values in comparisons of all dimensions between E. andium and E. insulatus; between E. andium and E. occidentalis; and between E. insulatus and E. occidentalis. Significant values were also found with respect to comparisons of dimensions 1, 3, 5, and 7 between $E$. andium and E. neogeus; with respect to comparisons of dimension 1 between $E$. insulatus and E. neogeus; and with respect to comparisons of dimension 7 between E. neogeus and E. occidentalis. All other comparisons resulted in non-significant values.

\section{Fossil Record Update}

In updating the known distribution of Equus fossil sites in South America, 152 localities were found (Table 4), making it possible to observe the very widespread distribution of the genus throughout the continent (Figure 10; Alberdi and Prado, 1992, 2004; Prado and Alberdi, 1994; Faure et al., 1999; MacFadden et al., 1999; Alberdi and Frassineti, 2000; Frassinetti and Alberdi,
2001; Alberdi et al., 2003; Porpino et al., 2004; Pujos and Salas, 2004; Dantas et al., 2005; Labarca and López, 2006; Rincón et al., 2006; Araújo-Junior and Porpino, 2007; Mendoza, 2007; Dias Neto et al., 2008; Hubbe, 2008; Kerber and Oliveira, 2008a; Kerber and Oliveria, 2008b; Ximenes, 2008; Borrero, 2009; Scheffler et al., 2010; Silva et al., 2010, 2012; França et al., 2011; Prado et al., 2011; Recabarren et al., 2011; Pereira et al., 2012; Román-Carrión, 2012; Nogueira and Barbosa, 2015; Suárez and Santos, 2015; Avilla et al., 2018).

The genus Equus spread through most of the South American continent, occupying highlands and lowlands (Figure 11). Although most records indicate altitudes of $<500 \mathrm{~m}$, there are several records over almost $3,000 \mathrm{~m}$, and there are no records south of latitude $40^{\circ} \mathrm{S}$.

\section{DISCUSSION}

The state of the art of South American native Equus taxonomy was dominated by a splitter tendency beginning in the second half of the nineteenth century, when several poorly diagnosed species were named. Most of these species were maintained until the second half of twentieth century, when a stable taxonomy of South American native Equus was finally achieved (Hoffstetter, 1950; Alberdi and Prado, 1992; Prado and Alberdi, 2017). 
TABLE 2 | Kruskal-Wallis test results for comparative analysis of MCIII.

\begin{tabular}{|c|c|c|c|c|c|}
\hline & 1 & 3 & 4 & 5 & 10 \\
\hline E. andium vs. E. insulatus & $p<0.05$ & $p<0.05$ & $p<0.05$ & $p<0.05$ & $p<0.05$ \\
\hline E. andium vs. E. neogeus & $p<0.05$ & $p<0.05$ & $p<0.05$ & $p<0.05$ & $p<0.05$ \\
\hline E. andium vs. E. occidentalis & $p<0.05$ & $p<0.05$ & $p<0.05$ & $p<0.05$ & $p<0.05$ \\
\hline E. insulatus vs. E. neogeus & $p<0.05$ & ns & ns & ns & ns \\
\hline E. insulatus vs. E. occidentalis & $p<0.05$ & $p<0.05$ & $p<0.05$ & $p<0.05$ & $p<0.05$ \\
\hline E. neogeus vs. E. occidentalis & ns & ns & ns & ns & ns \\
\hline
\end{tabular}

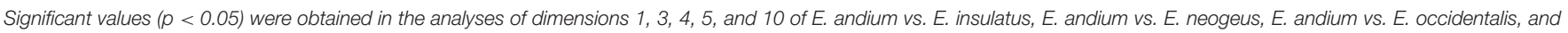
E. insulatus vs. E. occidentalis, and in the analysis of dimension 1 of E. insulatus vs. E. neogeus; non-significant values were found for all other analyses.

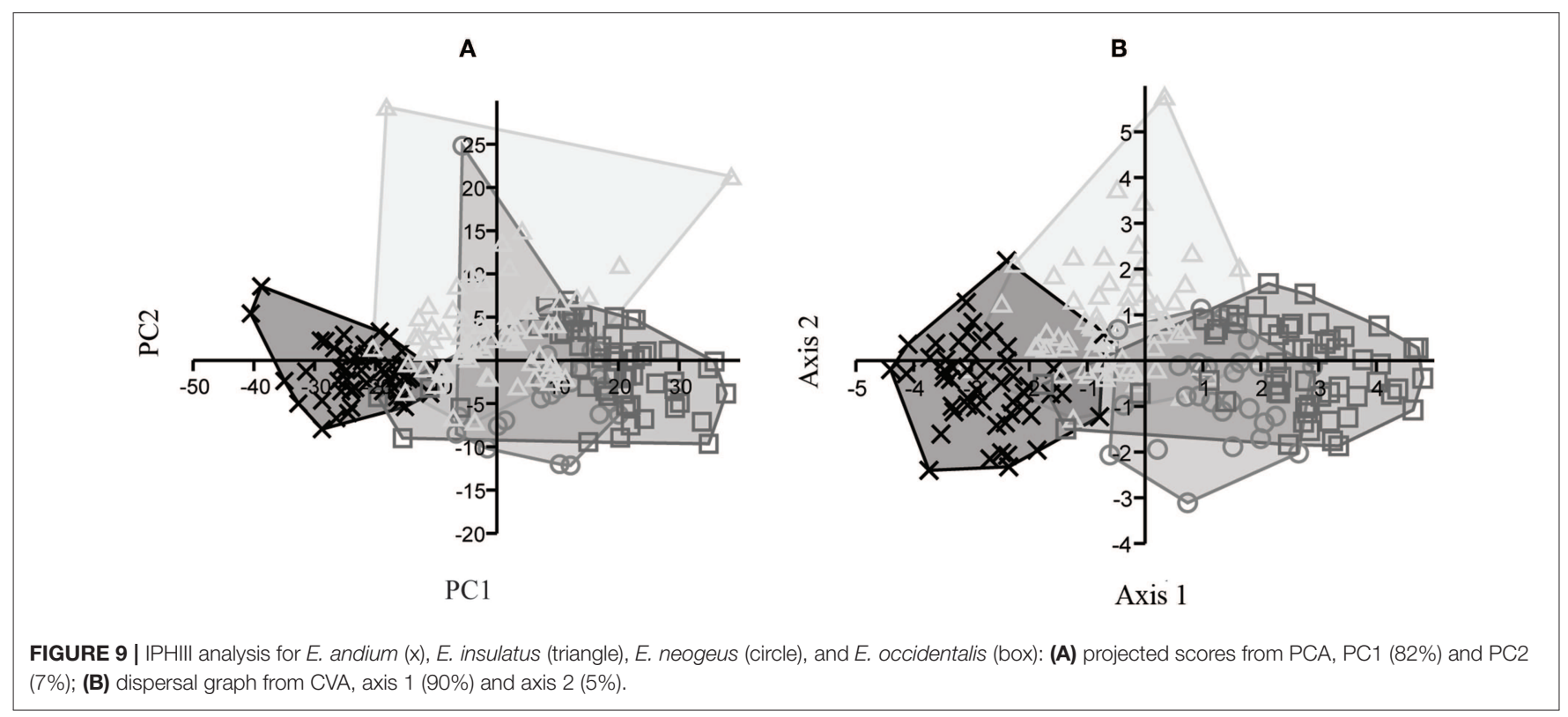

Size was assumed to be the best (and even only) basis for diagnosing South American Equus species within this group, and this consensus held until the end of the 2010s (Machado, 2018; Machado et al., 2018). The results obtained in the present study revealed that it is not possible to distinguish between South American Equus based on the morphological characters previously used: size, and the proportions of the autopodia and teeth.

Dental analyses revealed a clear overlap in tooth proportions among the species. The results demonstrated that dimensions 2 and 4 for the upper cheek teeth, and dimensions 2 and 6 for the lower cheek teeth, were the most important variables in the PCA. Even these variables, however, were not sufficient to differentiate among the species.

These results were in accordance with the autopodial analysis, which corroborated all the analyses performed by Machado et al. (2018). The bivariate analysis, PCA and CVA that were carried out on autopodial measurements revealed not only a clear overlap between all the species, but also a continuum of gradual linear variation. This continuum was already observed in Machado et al. (2018), and the superimposition of autopodial metric characters was even more clearly observed in the present study, which included more data.

PCA revealed that the most significant variables in the case of PC1 were measurements 1 and 2 of MTIII, MCIII and IPHIII. PC1 was responsible for over $90 \%$ of the variation in each case except that of the IPHIII analysis, in which it was responsible for $82 \%$. Thus, length was the most significant character in the autopodial analyses but was still not sufficient to distinguish among the species. Instead length showed a continuum of gradual linear variation. These analyses were corroborated by the Kruskal-Wallis test, which found significant values only in the comparison of species on the extremities of the continuum. The only species found to be somewhat distinct from the others, both on axis 1 in the CVA of MTIII and MCIII and in the KruskalWallis test, was the North American E. occidentalis. Furthermore, E. occidentalis can be distinguished from the South American species by diagnostic cranial characters according to MacFadden and Azzaroli (1987).

Considering the complete overlap seen in the autopodial and dental metric characters, it is inferred here, as proposed by Machado (2018) and Machado et al. (2018), that South America was probably inhabited by only a single species of Equus, E. 
TABLE 3 | Kruskal-Wallis test results for comparative analysis of IPHIII.

\begin{tabular}{|c|c|c|c|c|c|}
\hline & 1 & 3 & 5 & 7 & 8 \\
\hline E. andium vs. E. insulatus & $p<0.05$ & $p<0.05$ & $p<0.05$ & $p<0.05$ & $p<0.05$ \\
\hline E. andium vs. E. neogeus & $p<0.05$ & $p<0.05$ & $p<0.05$ & $p<0.05$ & ns \\
\hline E. andium vs. E. occidentalis & $p<0.05$ & $p<0.05$ & $p<0.05$ & $p<0.05$ & $p<0.05$ \\
\hline E. insulatus vs. E. neogeus & $p<0.05$ & ns & ns & ns & ns \\
\hline E. insulatus vs. E. occidentalis & $p<0.05$ & $p<0.05$ & $p<0.05$ & $p<0.05$ & $p<0.05$ \\
\hline E. neogeus vs. E. occidentalis & ns & ns & ns & $p<0.05$ & ns \\
\hline
\end{tabular}

Significant values $(p<0.05)$ were obtained in the analyses of dimensions $1,3,5,7$, and 8 of E. andium vs. E. insulatus, E. andium vs. E. occidentalis, and E. insulatus vs. E. occidentalis,

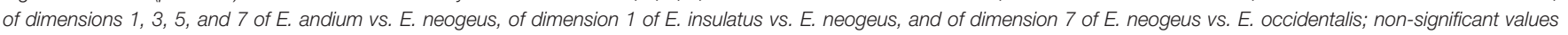
were found for all other analyses.

neogeus. However, the continuum observed in the autopodial analyses indicates an intraspecific variation that allows the establishment of a phenotypic variation according to the species in the extremities, even though it cannot be used to distinguish any distinct groupings.

Morphological analyses allow the interpretation of a vast variety of biological processes that can result in morphological differences between individuals and populations, either through a long period of genetic divergence or by phenotypic plasticity oriented by the environment (Kangas et al., 2016). Morphological variations related to biotic and abiotic gradients in heterogeneous environments are commonly observed in species with wide geographic distributions (Salomon, 2001; Ennen et al., 2014). Intraspecific variation analyses are common in morphological studies of ungulates, and several groups display a relationship between morphological phenotypic variation and latitudinal variation (Kangas et al., 2016). Examples of this relationship usually conform to Bergmann's Rule (Bergmann, 1848 in Mayr, 1963a,b), which posits a correlation between larger bodies and higher altitudes or cold environments, often considered an adaptation to climatic variations (Ashton et al., 2000; Blackburn and Hawkins, 2004; Kangas et al., 2016). However, the phenotypic variation observed in South American Equus is different and does not fit the latitudinal variation pattern, so the possibility that it represents a case of Bergmann's Rule can be excluded. Allen's Rule is also commonly invoked when dealing with phenotypic and latitudinal variations and implies a correlation between shorter appendages, and therefore shorter limb bones, and colder environments in endothermic mammals (Nudds and Oswald, 2007; Symonds and Tattersall, 2010; Alho et al., 2011). This rule likewise does not seem to explain the variation observed in Equus in South America. There are records of long limb bone morphotypes in localities with colder environments, such as those at latitude $40^{\circ} \mathrm{S}$, and also in areas characterized by a greater range of phenotypic variation. Ecuador, for example, was once believed to have three species distinguished by limb bone proportions. It was once postulated that the Gracility Index of South American Equus autopodia, and especially of IPHIII, was related to the environment, with slenderness linked to harder ground and robustness to softer ground (Prado and Alberdi, 1994; Alberdi and Prado, 2004). However, recent studies (Machado et al., 2018) have refuted this idea and revealed that the Gracility Index has a negatively allometric relationship with bone length.

The genus Equus has a continuous geographic distribution in South America, bypassing the Amazon region, and this pattern seems to be correlated with phenotypic variation in E. neogeus. The Amazon basin was the region of South America most strongly affected by Pleistocene climatic variations, with constant alternations between contraction and expansion of the tropical forest (Arruda et al., 2017). The Amazon forest constituted a relatively warm and wet habitat that probably remained isolated through much of the Pleistocene (Arruda et al., 2017). However, Equus usually favor open plain environments, like savannas (MacFadden, 1994; Alberdi and Prado, 2004; Costa, 2017; Prado and Alberdi, 2017), and the typical environmental instability of closed forest biomes might have worked as a geographic barrier to dispersion of the genus in the South American continent. Most records indicate altitudes as high as 500 meters, with several records approaching 3,000 $\mathrm{m}$ and this approximate altitude was probably a limit for the taxon. There are no records south of latitude $40^{\circ} \mathrm{S}$, a pattern that is also observed in other Pleistocene mammals, such as Notiomastodon platensis (Mothé and Avilla, 2015). This distribution also differs importantly from that of Hippidion, the other South American equid, for which records are limited to southern Patagonia but surpassing latitude $50^{\circ} \mathrm{S}$ (Prado and Alberdi, 2017). According to Ray and Adams (2001), during the Last Glacial Maximum, the environment at latitudes exceeding $40^{\circ} \mathrm{S}$ corresponded to a temperate desert with permanent ice sheets at the southern area of the continent, which probably formed a barrier to the dispersal of Equus in South America. Furthermore, the geographic distribution of Equus in South America surrounds the Amazon. The possibility that the lack of Amazonian records of Equus is a result of taphonomic factors can be excluded, since Pleistocene records of other fossil mammals are known from the Amazon (Rancy, 1999).

As proposed by Machado et al. (2018) and Machado (2018), South American Equus appears to represent a case of clinal variation. Clines can be categorized as smooth or stepped, the former corresponding to gradual continua without marked intraspecific boundaries and the latter to continua with steeper slopes, abrupt changes and clear demarcations between possible subspecies (Salomon, 2001, 2002; Katzner and Collar, 2013). With increasing evolutionary differentiation, smooth clines 
TABLE 4 | Locations and altitudes of Equus fossil occurrences in South America.

\begin{tabular}{|c|c|c|c|}
\hline Localities & Country & Altitude & Latitude \\
\hline Napostá Grande (Bahía Blanca) & Argentina & $34 \mathrm{~m}$ & $38^{\circ} 8^{\prime} \mathrm{S}$ \\
\hline Arroyo Camet (Buenos Aires) & Argentina & $35 \mathrm{~m}$ & $37^{\circ} 49^{\prime} \mathrm{S}$ \\
\hline Arroyo Claromecó (Buenos Aires) & Argentina & $11 \mathrm{~m}$ & $38^{\circ} 51^{\prime} 6.67^{\prime \prime} \mathrm{S}$ \\
\hline Arroyo Tapalqué (Buenos Aires) & Argentina & $160 \mathrm{~m}$ & $36^{\circ} 58^{\prime} 15.71^{\prime \prime} \mathrm{S}$ \\
\hline Ayacucho (Buenos Aires) & Argentina & $79 m$ & $37^{\circ} 07^{\prime} 00^{\prime \prime} \mathrm{S}$ \\
\hline Ayacucho (Buenos Aires) & Argentina & $47 m$ & $31^{\circ} 07^{\prime} 00^{\prime \prime} \mathrm{S}$ \\
\hline Balcarce (Buenos Aires) & Argentina & $121 \mathrm{~m}$ & $37^{\circ} 8333 \mathrm{~S}$ \\
\hline Bahía San Blas (Buenos Aires) & Argentina & $5 \mathrm{~m}$ & $40^{\circ} 33^{\prime} 08^{\prime \prime} \mathrm{S}$ \\
\hline Barrancas (Buenos Aires) & Argentina & $8 \mathrm{~m}$ & $38^{\circ} 44^{\prime} 32.50^{\prime \prime} \mathrm{S}$ \\
\hline Buenos Aires (Buenos Aires) & Argentina & $29 m$ & $34^{\circ} 35^{\prime} 08.8^{\prime \prime} \mathrm{S}$ \\
\hline Campo Spósito (Buenos Aires) & Argentina & $278 m$ & \\
\hline Centinela del Mar (Buenos Aires) & Argentina & $13 \mathrm{~m}$ & $38^{\circ} 26^{\prime} 00^{\prime \prime} \mathrm{S}$ \\
\hline Chacra del Brié (Buenos Aires) & Argentina & $204 \mathrm{~m}$ & $37^{\circ} 19^{\prime} 43.65^{\prime \prime} \mathrm{S}$ \\
\hline Chascomús (Buenos Aires) & Argentina & $19 m$ & $35^{\circ} 36^{\prime} \mathrm{S}$ \\
\hline González Chaves (Buenos Aires) & Argentina & $199 m$ & \\
\hline Indio Rico (Buenos Aires) & Argentina & $143 m$ & $38^{\circ} 33^{\prime} 3^{\prime \prime} \mathrm{S}$ \\
\hline La Chata (Buenos Aires) & Argentina & $20 \mathrm{~m}$ & $38^{\circ} 33^{\prime} 16.50^{\prime \prime} \mathrm{S}$ \\
\hline Las Conchas (Buenos Aires) & Argentina & $13 m$ & $34^{\circ} 25^{\prime} 17.26^{\prime \prime} \mathrm{S}$ \\
\hline La Plata (Buenos Aires) & Argentina & $28 \mathrm{~m}$ & $34^{\circ} 54^{\prime} 04.5^{\prime \prime} \mathrm{S}$ \\
\hline Lobos (Buenos Aires) & Argentina & $33 \mathrm{~m}$ & $35^{\circ} 11^{\prime} 7^{\prime \prime} \mathrm{S}$ \\
\hline Malacara (Buenos Aires) & Argentina & $37 \mathrm{~m}$ & $34^{\circ} 24^{\prime} 52.71^{\prime \prime} \mathrm{S}$ \\
\hline Magdalena (Buenos Aires) & Argentina & $11 \mathrm{~m}$ & $35^{\circ} 4^{\prime} 35.40^{\prime \prime} \mathrm{S}$ \\
\hline Mar del Plata (Buenos Aires) & Argentina & $443 m$ & $38^{\circ} 00^{\prime} 16.2^{\prime \prime} \mathrm{S}$ \\
\hline Mercedes (Buenos Aires) & Argentina & $44 \mathrm{~m}$ & $34^{\circ} 39^{\prime} 16.57^{\prime \prime} \mathrm{S}$ \\
\hline Miembro Guerrero (Buenos Aires) & Argentina & ? & $35^{\circ} \mathrm{S}$ \\
\hline Miramar (Buenos Aires) & Argentina & $20 \mathrm{~m}$ & $38^{\circ} 16^{\prime} 13.25^{\prime \prime} \mathrm{S}$ \\
\hline Monte Hermoso (Buenos Aires) & Argentina & $8 m$ & $38^{\circ} 59^{\prime} 15.5^{\prime \prime} \mathrm{S}$ \\
\hline Necochea (Buenos Aires) & Argentina & $18 m$ & $38^{\circ} 12^{\prime} 08^{\prime \prime} \mathrm{S}$ \\
\hline Olavarría (Buenos Aires) & Argentina & $170 \mathrm{~m}$ & $36^{\circ} 58^{\prime} 44^{\prime \prime} \mathrm{S}$ \\
\hline Paso Otero (Buenos Aires) & Argentina & $10 \mathrm{~m}$ & $38^{\circ} 12^{\prime \prime} 08^{\prime \prime} \mathrm{S}$ \\
\hline Pehuen Có (Buenos Aires) & Argentina & $7 \mathrm{~m}$ & $39^{\circ} 0^{\prime} 0^{\prime \prime} S$ \\
\hline Playa del Barco (Buenos Aires) & Argentina & $1 \mathrm{~m}$ & $39^{\circ} 00^{\prime} 09^{\prime \prime} \mathrm{S}$ \\
\hline Paso del Médano (Buenos Aires) & Argentina & $8 m$ & $38^{\circ} 44^{\prime} 32.50^{\prime \prime} \mathrm{S}$ \\
\hline Punta Carballitos (Buenos Aires) & Argentina & $107 \mathrm{~m}$ & $38^{\circ} 53^{\prime} 33^{\prime \prime} \mathrm{S}$ \\
\hline Punta Hermengo (Buenos Aires) & Argentina & $20 \mathrm{~m}$ & $38^{\circ} 16^{\prime} 13.25^{\prime \prime} \mathrm{S}$ \\
\hline Quequén Grande (Buenos Aires) & Argentina & $107 \mathrm{~m}$ & $38^{\circ} 16^{\prime} 58.9^{\prime \prime} \mathrm{S}$ \\
\hline Rio Luján (Buenos Aires) & Argentina & $21 \mathrm{~m}$ & $34^{\circ} 33^{\prime} 58.9^{\prime \prime} \mathrm{S}$ \\
\hline Río de La Plata (Buenos Aires) & Argentina & $22 \mathrm{~m}$ & $34^{\circ} 30^{\prime} 37.99^{\prime \prime} \mathrm{S}$ \\
\hline Rio Sauce Grande (Buenos Aires) & Argentina & $11 \mathrm{~m}$ & $38^{\circ} 49^{\prime} 51.2^{\prime \prime} \mathrm{S}$ \\
\hline Rio Quequén Salado (Buenos Aires) & Argentina & $8 m$ & $35^{\circ} 37^{\prime} 36.6^{\prime \prime} \mathrm{S}$ \\
\hline Tandil (Buenos Aires) & Argentina & $204 \mathrm{~m}$ & $37^{\circ} 19^{\prime} 43.65^{\prime \prime} \mathrm{S}$ \\
\hline Tapalqué (Buenos Aires) & Argentina & $90 \mathrm{~m}$ & $36^{\circ} 21^{\prime} 21.3^{\prime \prime} \mathrm{S}$ \\
\hline Tres Arroyos (Buenos Aires) & Argentina & $115 \mathrm{~m}$ & $38^{\circ} 23^{\prime} 0^{\prime \prime} \mathrm{S}$ \\
\hline Vicente López (Buenos Aires) & Argentina & $26 \mathrm{~m}$ & $34^{\circ} \mathrm{S}$ \\
\hline Wilde (Buenos Aires) & Argentina & $7 \mathrm{~m}$ & $34^{\circ} 41^{\prime} 54^{\prime \prime} \mathrm{S}$ \\
\hline Mar Chiquita (Córdoba) & Argentina & $2 \mathrm{~m}$ & $37^{\circ} 40^{\prime} \mathrm{S}$ \\
\hline San Francisco (Córdoba) & Argentina & $422 \mathrm{~m}$ & $31^{\circ} 26^{\prime} \mathrm{S}$ \\
\hline Sitio El Silencio (Córdoba) & Argentina & $18 \mathrm{~m}$ & $30^{\circ} 53^{\prime} 20^{\prime \prime} \mathrm{S}$ \\
\hline Arroyo Alcaráz (Entre Ríos) & Argentina & $47 \mathrm{~m}$ & $31^{\circ} 5^{\prime} 27.6^{\prime \prime} \mathrm{S}$ \\
\hline Arroyo Ensenada (Entre Ríos) & Argentina & $6 \mathrm{~m}$ & $31^{\circ} 85^{\prime} \mathrm{S}$ \\
\hline
\end{tabular}

(Continued)
TABLE 4 | Continued

\begin{tabular}{|c|c|c|c|}
\hline Localities & Country & Altitude & Latitude \\
\hline El Boyero (Entre Ríos) & Argentina & $27 \mathrm{~m}$ & $31^{\circ} 25^{\prime} \mathrm{S}$ \\
\hline Espinillo (Entre Ríos) & Argentina & $88 \mathrm{~m}$ & $24^{\circ} 58^{\prime} 0^{\prime \prime} \mathrm{S}$ \\
\hline Zanjón Seco (Jujuy) & Argentina & $1,034 \mathrm{~m}$ & $38^{\circ} 10^{\prime} 7^{\prime \prime} \mathrm{S}$ \\
\hline Laguna Meum & Argentina & $23 \mathrm{~m}$ & $34.64352 \mathrm{~S}$ \\
\hline El Carriza (Mendoza) & Argentina & $786 \mathrm{~m}$ & $32^{\circ} 20^{\prime} 20^{\prime \prime} \mathrm{S}$ \\
\hline Gruta del Indio (Mendoza) & Argentina & $114 \mathrm{~m}$ & $34^{\circ} 45^{\prime} \mathrm{S}$ \\
\hline Malargüe (Mendoza) & Argentina & $1,198 \mathrm{~m}$ & $35^{\circ} 28^{\prime} 32^{\prime \prime} \mathrm{S}$ \\
\hline Cañada Honda (San Luis) & Argentina & $611 \mathrm{~m}$ & $31^{\circ} 58^{\prime} 49.5^{\prime \prime} \mathrm{S}$ \\
\hline Inti Huasi (San Luis) & Argentina & $17 \mathrm{~m}$ & $37.25193 \mathrm{~S}$ \\
\hline Río Seco de Chical (San Luis) & Argentina & $696 \mathrm{~m}$ & $32^{\circ} 75^{\prime} \mathrm{S}$ \\
\hline Alvear (Santa Fe) & Argentina & $63 \mathrm{~m}$ & $33^{\circ} \mathrm{S}$ \\
\hline Arroyo Frías (Santa Fe) & Argentina & $30 \mathrm{~m}$ & $33^{\circ} 9^{\prime} 0^{\prime \prime} \mathrm{S}$ \\
\hline Arroyo Seco (Santa Fe) & Argentina & $30 \mathrm{~m}$ & $33^{\circ} 9^{\prime} 0^{\prime \prime} \mathrm{S}$ \\
\hline Cercanías (Santa Fe) & Argentina & $42 \mathrm{~m}$ & $31^{\circ} 27^{\prime} 0^{\prime \prime} \mathrm{S}$ \\
\hline Chaco Santafesino (Santa Fe) & Argentina & $56 m$ & $27^{\circ} 27^{\prime} 05^{\prime \prime} \mathrm{S}$ \\
\hline Esperanza (Santa Fe) & Argentina & $42 m$ & $31^{\circ} 27^{\prime} \mathrm{O}^{\prime \prime} \mathrm{S}$ \\
\hline Laguna Setubal (Santa Fe) & Argentina & $11 \mathrm{~m}$ & $31^{\circ} 33^{\prime} 37.5^{\prime \prime} \mathrm{S}$ \\
\hline Puerto San Martín (Santa Fe) & Argentina & $663 \mathrm{~m}$ & $33^{\circ} \mathrm{S}$ \\
\hline Puerto San Martín (Santa Fe) & Argentina & $26 \mathrm{~m}$ & $32^{\circ} 44^{\prime} 29^{\prime \prime} \mathrm{S}$ \\
\hline Río Dulce (Santiago del Estero) & Argentina & $153 \mathrm{~m}$ & $27^{\circ} 47^{\prime} 0.14^{\prime \prime} \mathrm{S}$ \\
\hline Rio Carcarañá (Santa Fe) & Argentina & $84 \mathrm{~m}$ & $32^{\circ} 51^{\prime} 06.3^{\prime \prime} \mathrm{S}$ \\
\hline Rio Paraná (Santa Fe) & Argentina & $34 \mathrm{~m}$ & $33^{\circ} 2^{\prime} 29.60^{\prime \prime} \mathrm{S}$ \\
\hline Río Salado (Santa Fe) & Argentina & $22 \mathrm{~m}$ & $31^{\circ} 37^{\prime} 45.4^{\prime \prime} \mathrm{S}$ \\
\hline Rosario (Santa Fe) & Argentina & $84 \mathrm{~m}$ & $33^{\circ} 5^{\prime} 32.85^{\prime \prime} \mathrm{S}$ \\
\hline Tacural (Santa Fe) & Argentina & $98 \mathrm{~m}$ & $30^{\circ} 83^{\prime} 3^{\prime \prime} \mathrm{S}$ \\
\hline La Banda (Santiago del Estero) & Argentina & $193 \mathrm{~m}$ & $27^{\circ} 44^{\prime} 9.02^{\prime \prime} \mathrm{S}$ \\
\hline Nuapa (Chuquisaca) & Bolivia & $1,856 \mathrm{~m}$ & $20^{\circ} 00^{\prime} 0.00^{\prime \prime} \mathrm{S}$ \\
\hline Tarija (Tarija) & Bolivia & $1,603 \mathrm{~m}$ & $21^{\circ} 31^{\prime} 56^{\prime \prime} \mathrm{S}$ \\
\hline Lagoa de Pedra (Alagoas) & Brazil & $309 m$ & $9^{\circ} 32^{\prime} 13^{\prime \prime} \mathrm{s}$ \\
\hline Chique-Chique (Bahia) & Brazil & $408 m$ & $10^{\circ} 49^{\prime} 23^{\prime \prime} \mathrm{S}$ \\
\hline Curaçá (Bahia) & Brazil & $364 \mathrm{~m}$ & $08^{\circ} 59^{\prime} 31^{\prime \prime} \mathrm{s}$ \\
\hline Itaguaçu (Bahia) & Brazil & $422 \mathrm{~m}$ & $11^{\circ} 01^{\prime} 46.6^{\prime \prime} \mathrm{S}$ \\
\hline Ourolândia (Bahia) & Brazil & $597 \mathrm{~m}$ & $10^{\circ} 55^{\prime} 52^{\prime \prime} \mathrm{S}$ \\
\hline Toca dos Ossos (Bahia) & Brazil & $597 \mathrm{~m}$ & $10^{\circ} 55^{\prime} 52^{\prime \prime} \mathrm{S}$ \\
\hline Waterwhole deposit (Bahia) & Brazil & $775 \mathrm{~m}$ & $10.46667 \mathrm{~S}$ \\
\hline Itapipoca (Ceará) & Brazil & $106 \mathrm{~m}$ & $3^{\circ} 29^{\prime} 59.32^{\prime \prime} \mathrm{S}$ \\
\hline Corumbá (Mato Grosso do Sul) & Brazil & $153 m$ & $18^{\circ} 58^{\prime} 48^{\prime \prime} \mathrm{S}$ \\
\hline Águas do Araxá (Minas Gerais) & Brazil & $976 m$ & $19^{\circ} 50^{\prime} 09^{\prime \prime} \mathrm{S}$ \\
\hline Francisco Sá (Minas Gerais) & Brazil & $670 m$ & $16^{\circ} 29^{\prime} \mathrm{S}$ \\
\hline Lagoa Santa (Minas Gerais) & Brazil & $772 m$ & $19^{\circ} 38^{\prime} \mathrm{S}$ \\
\hline Curimatã (Paraíba) & Brazil & $357 \mathrm{~m}$ & $7^{\circ} 43^{\prime} 36^{\prime \prime} \mathrm{S}$ \\
\hline Taperoá (Paraíba) & Brazil & $537 \mathrm{~m}$ & $7^{\circ} 12^{\prime} 2.86^{\prime \prime} \mathrm{S}$ \\
\hline Mangueirinhia (Paraná) & Brazil & $912 \mathrm{~m}$ & $25^{\circ} 47^{\prime} 30^{\prime \prime} \mathrm{S}$ \\
\hline Alagoinha (Pernambuco) & Brazil & $310 \mathrm{~m}$ & $8^{\circ} 24^{\prime} \mathrm{S}$ \\
\hline Afrânio (Pernambuco) & Brazil & $477 \mathrm{~m}$ & $8^{\circ} 30^{\prime} 54^{\prime \prime} \mathrm{S}$ \\
\hline Pesqueira (Pernambuco) & Brazil & $714 m$ & $8^{\circ} 24^{\prime} \mathrm{S}$ \\
\hline São Raimundo Nonato (Piauil) & Brazil & $346 \mathrm{~m}$ & $9^{\circ} 00^{\prime} 55^{\prime \prime} \mathrm{s}$ \\
\hline Toca do Serrote do Artur (Piauí) & Brazil & $371 \mathrm{~m}$ & $8^{\circ} 49^{\prime} 35^{\prime \prime} \mathrm{S}$ \\
\hline Ponte Velha II (Rio Grande do Sul) & Brazil & $156 \mathrm{~m}$ & $29^{\circ} 39^{\prime} 45.46^{\prime \prime} \mathrm{S}$ \\
\hline Quaraí (Rio Grande do Sul) & Brazil & $107 \mathrm{~m}$ & $30^{\circ} 10^{\prime} \mathrm{S}$ \\
\hline
\end{tabular}

(Continued) 
TABLE 4 | Continued

\begin{tabular}{|c|c|c|c|}
\hline Localities & Country & Altitude & Latitude \\
\hline $\begin{array}{l}\text { Santa Vitória do Palmar (Rio Grande } \\
\text { do Sul) }\end{array}$ & Brazil & $14 \mathrm{~m}$ & $33^{\circ} 44^{\prime} 11.4^{\prime \prime} \mathrm{S}$ \\
\hline $\begin{array}{l}\text { Lajedo de Soledade (Rio Grande do } \\
\text { Norte) }\end{array}$ & Brazil & $121 \mathrm{~m}$ & $5^{\circ} 35^{\prime} 20^{\prime \prime} \mathrm{S}$ \\
\hline São Rafael (Rio Grande do Norte) & Brazil & $83 \mathrm{~m}$ & $5^{\circ} 50^{\prime} \mathrm{S}$ \\
\hline Gararu (Sergipe) & Brazil & $161 \mathrm{~m}$ & $37^{\circ} 05^{\prime} 33^{\prime \prime} \mathrm{S}$ \\
\hline Poço Redondo (Sergipe) & Brazil & $193 \mathrm{~m}$ & $9^{\circ} 55^{\prime} 37^{\prime \prime} \mathrm{S}$ \\
\hline Aurora do Tocantins (Tocantins) & Brazil & $468 \mathrm{~m}$ & $12^{\circ} 35^{\prime} 0.08^{\prime \prime} \mathrm{S}$ \\
\hline Tuina (Atacama) & Chile & $2,642 \mathrm{~m}$ & $22^{\circ} 35^{\prime} \mathrm{S}$ \\
\hline San Vicente de Tagua (Cachapoal) & Chile & $208 \mathrm{~m}$ & $34^{\circ} 28^{\prime} 18^{\prime \prime} \mathrm{S}$ \\
\hline Cerro Caracol (Concepción) & Chile & $60 \mathrm{~m}$ & $36^{\circ} 50^{\prime} 03^{\prime \prime} \mathrm{S}$ \\
\hline Los Vilos (Coquimbo) & Chile & $18 \mathrm{~m}$ & $31^{\circ} 51^{\prime} \mathrm{S}$ \\
\hline Valle de Elqui (Elqui) & Chile & $123 \mathrm{~m}$ & $29^{\circ} 50^{\prime} \mathrm{S}$ \\
\hline Estero de Coyanco (La Laja) & Chile & $2,134 \mathrm{~m}$ & $33^{\circ} 40^{\prime} 59^{\prime \prime} \mathrm{S}$ \\
\hline Tierra Blancas (La Lingua) & Chile & $701 \mathrm{~m}$ & $32^{\circ} 27^{\prime} 00^{\prime \prime} \mathrm{S}$ \\
\hline Calera (Lo Aguirre) & Chile & $211 \mathrm{~m}$ & $32^{\circ} 47^{\prime} 00^{\prime \prime} \mathrm{S}$ \\
\hline Pilauco Site (Osorno) & Chile & $63 \mathrm{~m}$ & $40^{\circ} 34^{\prime} 11^{\prime \prime} \mathrm{S}$ \\
\hline Cachabuco (Santiago) & Chile & $642 \mathrm{~m}$ & $33^{\circ} 12^{\prime} \mathrm{S}$ \\
\hline Chacabuco (Santiago) & Chile & $544 m$ & $33^{\circ} 01^{\prime} 40^{\prime \prime} \mathrm{S}$ \\
\hline Colina (Santiago) & Chile & $597 \mathrm{~m}$ & $33^{\circ} 12^{\prime} 00^{\prime \prime} \mathrm{S}$ \\
\hline Conchalí (Santiago) & Chile & $1,356 \mathrm{~m}$ & $31^{\circ} 53^{\prime} \mathrm{S}$ \\
\hline Punta de Rieles (Santiago) & Chile & $574 m$ & $33.48101 \mathrm{~S}$ \\
\hline San Bernardo (Santiago) & Chile & $571 \mathrm{~m}$ & $33^{\circ} 12^{\prime} \mathrm{S}$ \\
\hline Huimpil (Temuco) & Chile & $257 \mathrm{~m}$ & $38^{\circ} 45^{\prime} \mathrm{O}^{\prime \prime} \mathrm{S}$ \\
\hline Sabana de Bogotá (Bogotá) & Colombia & $2,796 \mathrm{~m}$ & $5^{\circ} 11^{\prime} 46.54^{\prime \prime} \mathrm{N}$ \\
\hline Tibitó (Cundinamarca) & Colombia & $2,559 \mathrm{~m}$ & $4^{\circ} 10^{\prime} 20^{\prime \prime} \mathrm{N}$ \\
\hline Zanjón Seco (Ginebra) & Colombia & $1,034 \mathrm{~m}$ & $3^{\circ} 75^{\prime} 52.8^{\prime \prime} \mathrm{S}$ \\
\hline Cerro Gordo (Guamo) & Colombia & $392 \mathrm{~m}$ & $4^{\circ} 10^{\prime} 20^{\prime \prime} \mathrm{N}$ \\
\hline Fm. Villavieja (Huila) & Colombia & $387 \mathrm{~m}$ & $3^{\circ} 13^{\prime} 08^{\prime \prime} N$ \\
\hline La Venta (Huila) & Colombia & $2,139 m$ & $3^{\circ} 18^{\prime} \mathrm{N}$ \\
\hline Chalán (Sucre) & Colombia & $294 m$ & $9^{\circ} 32^{\prime} 38^{\prime \prime} N$ \\
\hline Punín (Chimborazo) & Ecuador & $2,801 \mathrm{~m}$ & $1^{\circ} 46^{\prime} 00^{\prime \prime} \mathrm{S}$ \\
\hline La Carolina (Pichincha) & Ecuador & $2,768 \mathrm{~m}$ & $0^{\circ} 11^{\prime} 07.1^{\prime \prime} \mathrm{S}$ \\
\hline Alangasí (Quito) & Ecuador & $2,552 \mathrm{~m}$ & $0^{\circ} 18^{\prime} 25.19^{\prime \prime} \mathrm{S}$ \\
\hline El Colegio (Quito) & Ecuador & $2,850 \mathrm{~m}$ & $0^{\circ} 15^{\prime} 01.8^{\prime \prime} \mathrm{S}$ \\
\hline La Magdalena (Quito) & Ecuador & $2,802 \mathrm{~m}$ & $0^{\circ} 15^{\prime} \mathrm{S}$ \\
\hline La Ronda (Quito) & Ecuador & $2,801 \mathrm{~m}$ & $0^{\circ} 15^{\prime} \mathrm{s}$ \\
\hline Otón (Quito) & Ecuador & $2,779 m$ & $0^{\circ} 01^{\prime} 37.6^{\prime \prime} \mathrm{S}$ \\
\hline Quebrada Colarada (Quito) & Ecuador & $2,595 \mathrm{~m}$ & $1^{\circ} 46^{\prime} 45.9^{\prime \prime} \mathrm{S}$ \\
\hline Quebrada Grande (Quito) & Ecuador & $2,595 \mathrm{~m}$ & $0^{\circ} 09^{\prime} 58.5^{\prime \prime} \mathrm{S}$ \\
\hline Rio Chiche (Quito) & Ecuador & $2,398 m$ & $0^{\circ} 12^{\prime} 28.79^{\prime \prime} \mathrm{S}$ \\
\hline $\begin{array}{l}\text { Península de Santa Elena (Santa } \\
\text { Elena) }\end{array}$ & Ecuador & $2 m$ & $2^{\circ} 13^{\prime} S$ \\
\hline Sacaco (Arequipa) & Peru & $2,321 \mathrm{~m}$ & $15^{\circ} 30^{\prime} 36.3^{\prime \prime} \mathrm{S}$ \\
\hline Pampa de los Fósiles (Paijan) & Peru & $94 m$ & $7^{\circ} 43^{\prime} \mathrm{S}$ \\
\hline Talata Tar Pit (Talara) & Peru & $86 \mathrm{~m}$ & $4^{\circ} 33^{\prime} \mathrm{S}$ \\
\hline $\begin{array}{l}\text { Pikimachay Cave (Valle del } \\
\text { Ayacucho) }\end{array}$ & Peru & $2,718 m$ & $13^{\circ} 2^{\prime} 26.88^{\prime \prime} \mathrm{S}$ \\
\hline Rio Cuareim (Artigas) & Uruguay & $57 \mathrm{~m}$ & $30^{\circ} 16^{\prime} 08.29^{\prime \prime} \mathrm{s}$ \\
\hline Arroyo Sopas (Salto) & Uruguay & $90 \mathrm{~m}$ & $31^{\circ} 15^{\prime} \mathrm{S}$ \\
\hline Taima (Falcón) & Venezuela & $39 m$ & $11^{\circ} 29^{\prime} 54^{\prime \prime} \mathrm{N}$ \\
\hline Inciarte (Zulia) & Venezuela & $94 \mathrm{~m}$ & $10^{\circ} 47^{\prime} 00^{\prime \prime} \mathrm{N}$ \\
\hline
\end{tabular}

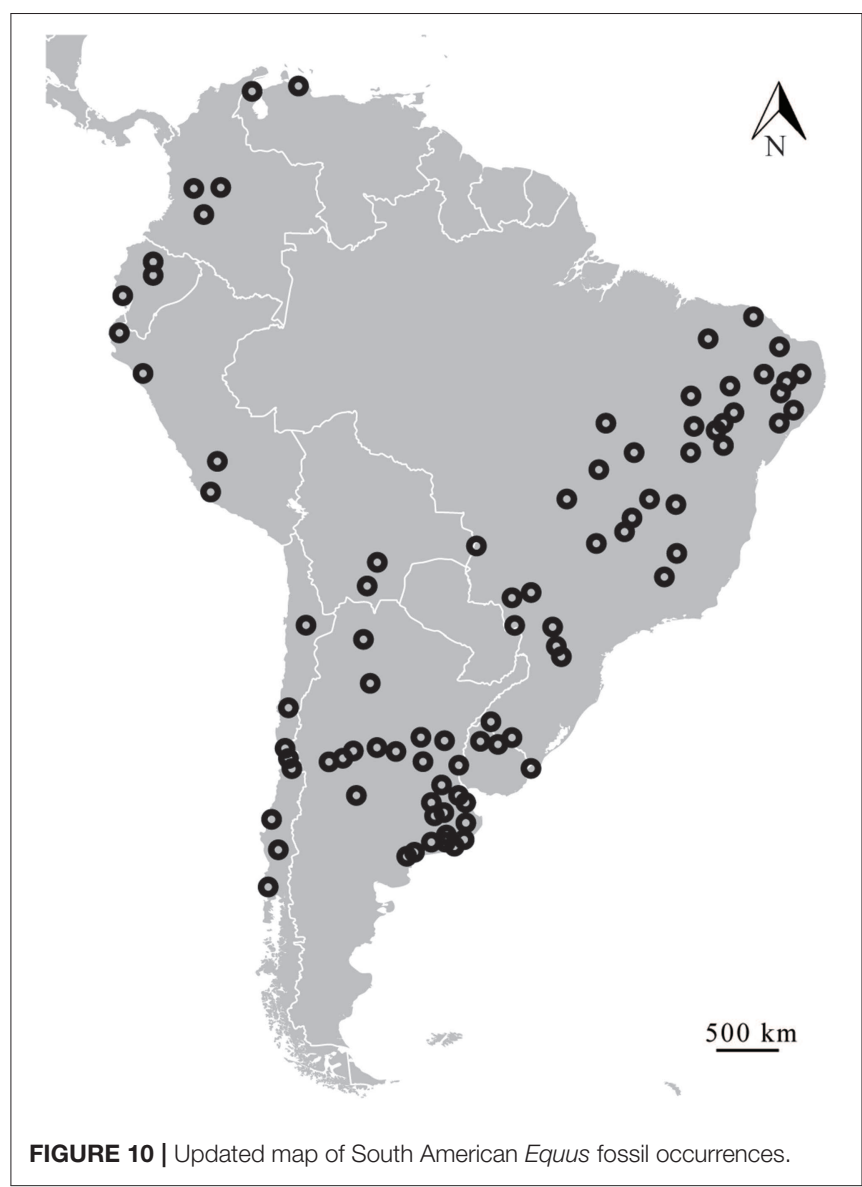

could gradually change into steeper ones. If the distinctions between adjacent populations within the cline become relatively large, the slopes occurring along the cline may turn into steps and potentially even "break" the cline, indicating some kind of speciation (Salomon, 2001, 2002). Considering the geographic distribution of Equus in South America along with the continuum of gradual linear variation observed in the autopodial analyses, which does not allow identification of marked intraspecific entities, it seems that South American Equus can be regarded as a smooth cline.

The lengths of the bones in the locomotor apparatus are usually related to cursoriality. In horse evolution this relationship is particularly evident in the distal bones, which tend to be longer in species inhabiting open and plains environments (Hildebrand, 1987; MacFadden, 1994; Christiansen, 2002; Alberdi and Prado, 2004). Still, maneuverability is related to mobility and to the ability to make rapid changes in speed and direction and is favored by a small body size (Hildebrand, 1987). The relation between body size and maneuverability is fundamentally based on Newton's First Law, the law of inertia (Newton, 1687). A larger body has more resistance to any change in its state of motion, and a smaller body is conversely characterized by lower resistance and consequently more maneuverability. Yet stability is related to the position of an individual's center of mass. For greater stability, the center of mass should be low and/or positioned over a large area 


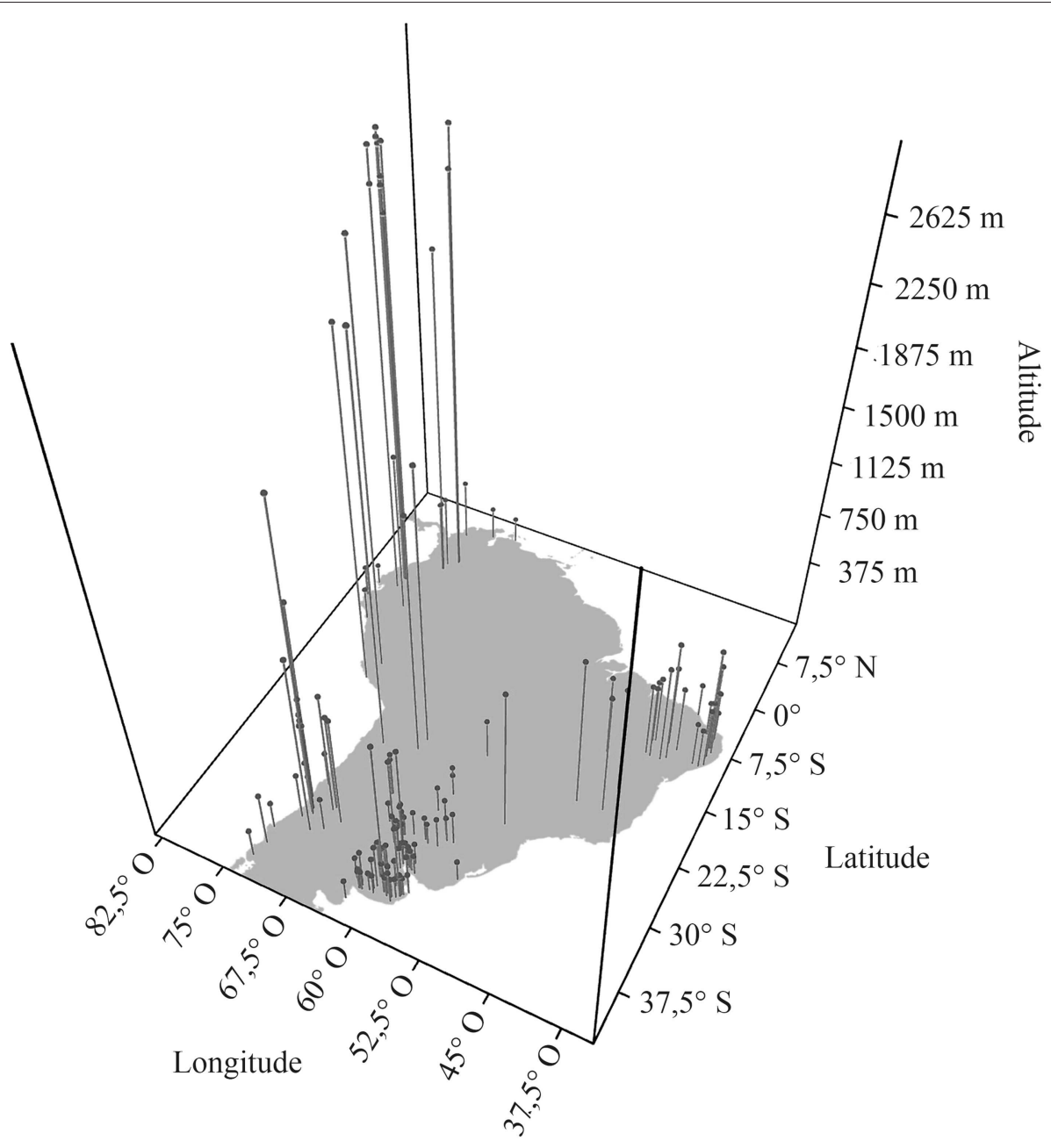

FIGURE 11 | Dispersal graph of the geographic coordinates and altitudes of South American Equus fossil occurrences.

delimited by the supporting feet, which is favored by short legs and large feet (Hildebrand, 1987).

Moreover, locomotion on sloping ground is different from locomotion on the plains, because in the former case postural readjustments are essential to propel the body and elevate the leg (Higgins and Ruff, 2011). These readjustments lead animals with shorter autopodials to have relatively higher step length on steep slopes, opposite to the pattern observed in plain environments (Higgins and Ruff, 2011). This tendency for species with shorter autopodials to occur in higher-altitude environments is observed in Perissodactyla: it applies to African zebras (Equidae, also of the genus Equus) from the mountains and the plains and, in Tapiridae, to Andean and plains tapirs (Machado, 2014). Within the Equidae, however, Asian asses present a distinct pattern, in which the higher altitude Equus species has longer limb bones than the ones from lower altitudes (Machado, 2014). Nonetheless, the Altiplano of Tibet differs from the African and Andean ones in being a plateau, consisting of a wide-open plain at high altitude (Moehlman, 2002). Thus, it seems that the observed variation in the limb proportions of South American Equus might have been driven by local topographic relief rather than altitude alone.
The taxonomy of South American Equus has always relied on dental and autopodial dimensions. Over almost two centuries, numerous species were identified based on unclear and biased diagnoses that were based primarily on size differences, ignoring the possibility that the observed morphological variations might not in fact be taxonomically diagnostic. Most review publications perpetuated this same idea, and for too long the taxonomy remained confusing and unclear. This contribution has analyzed a broader range of specimens from all over the continent, and from this greater picture it is possible to conclude that the dimensions of the teeth and autopodia are not diagnostic and therefore should not be used in the taxonomy of South American native Equus. Dental proportions showed clear superimposition among previously recognized species, and no marked species boundaries could be identified on this basis. Furthermore, autopodial analyses revealed clear superimposition with gradual linear variation, also without any marked intraspecific distinctions. It is inferred here that South America was inhabited by a single species of Equus, namely $E$. neogeus, and that its phenotypic variation represents a smooth cline probably driven by the type of topographic relief. 


\section{CONCLUSIONS}

The results obtained here support the conclusions of Machado et al. (2018), and it is proposed here that Equus in South America comprised a single species, Equus neogeus. The use of dimensions of teeth and autopodials in South American Equus as diagnostic features, as was done previously, is erroneous. Knowledge of the geographic distribution of Equus has been increased, showing that this genus was present in the majority of the continent, with the exceptions of the Amazon forest and latitudes south of $40^{\circ} \mathrm{S}$. The updated distributional map of South American Equus fossils, along with the autopodial analyses, allowed identification of a pattern that may represent a smooth cline of phenotypic variation correlating with topographic relief.

\section{DATA AVAILABILITY}

The datasets generated for this study are available on request to the corresponding author.

\section{AUTHOR CONTRIBUTIONS}

HM and LA were involved in all processes pertaining to the manuscript, from the collection's visits to the analyses and writing.

\section{ACKNOWLEDGMENTS}

The authors were grateful to the curators of the following institutions: Museu Nacional (MN) and Museu de Ciências Naturais da Pontifícia Universidade Católica de Minas Gerais

\section{REFERENCES}

Abel, O. (1913). "Säugetiere, Paläontologie," in Handwörterbuch der Naturwissenschaften 8: Iena, eds E. Korschelt, G. Link, F. Oltmans, S. Schaum, H. Th. Simon, M. Verworn, and E. Teichamann (Jena: Fischer), 696-759.

Alberdi, M. T., Cartelle, C., and Prado, J. L. (2003). El registro de Equus (Amerhippus) e Hippidion (Mammalia, Perissodactyla) de Brasil. Consideracionespaleoecológicas y biogeográficas. Ameghiniana 40, 173-196.

Alberdi, M. T., and Frassineti, D. (2000). Presencia de Hippidion y Equus (Amerhippus) (Mammalia, Perissodactyla) y su distribuicion em el Pleistoceno Superior de Chile. Estudios Geol. 56, 279-290. doi: 10.3989/egeol.00565-6144

Alberdi, M. T., and Prado, J. L. (1992). El registro de Hippidion Owen, 1869 y Equus (Amerhippus) Hoffstetter, 1950 (Mammalia, Perissodactyla) en America del Sur. Ameghiniana 29, 265-284.

Alberdi, M. T., and Prado, J. L. (1995). "Lós equidos de América del Sur," in Evolución Biológica y Climatic de Laregion Pampeana Durante los Últimos Cinco Millones de Años: Un Ensayo de Correlación con el Mediterráneo Occidental, M. T. Alberdi, G. Leone, and E. P. Tonni (Madrid: Consejo Superior de Inverstigaciones Cientificas), 295-307.

Alberdi, M. T., and Prado, J. L. (2004). "Caballos fósiles de América del Sur: uma historia de tres millones de años," in Serie Monográfica, Vol. 3, eds G. G. Politis and J. L. Prado (Buenos Aires: Incuapa), 259.

Alho, J. S., Herczeg, G., Laugen, A. T., Räsänen, K., Laurila, A., and Merilä, J. (2011). Allen's rule revisited: quantitative genetics of extremity length in the common frog along a latitudinal gradient. J. Evol. Biol. 24, 59-70. doi: 10.1111/j.1420-9101.2010.02141.x
(MCL), Brazil; Museo Argentino de Ciencias Naturales Bernardino Rivadavia (MACN-Pv) and Museo de La Plata (MLP), Argentina; Museo de Historia Natural Gustavo Orcés V (V and MECN), Ecuador; Museo Nacional Paleontología y Arquiología de Tarija (TAR), Bolivia; Museo de Historia Natural (UNMSM), Peru; Museo de Ciencias Naturales Federico Carlos Lehman, Colombia; and American Museum of Natural History (AMNH) and La Brea Tar Pits and Museum (previously the George C. Page Museum; GCPM), USA, for allowing access to the Equus collections that supported this study. HM and LA were also grateful for the feedback during the data analysis process from Dr. Orlando N. Grillo. HM and LA were thankful to reviewer 1 for the feedback, to reviewer 2 for the feedback and English corrections and suggestions on the manuscript, and to the editor Dr. Corwin Sullivan for the English review of the manuscript. HM was thankful to the Department of Earth Sciences of University of Oregon for financial support, and to the National Science Foundation (NSF) for financial support as a GE provided through the project Collaborative Research: ABI Innovation: FuTRES, an Ontology-Based Functional Trait Resource for Paleo- and Neo-biologists (1759821). LA was thankful to Dr. Bruce MacFadden for hosting him at the Florida Museum of Natural History and Science during his sabbatical in 2014/2015, to Conselho Nacional de Desenvolvimento Científico e Tecnológico $(\mathrm{CNPq})$ for a post-doctoral scholarship (248772/2013-9) awarded through the Program Ciências sem Fronteiras and for the research scholarship on the program. Bolsa de Produtividade em pesquisa (process 307555/2016-0), and for financial support provided by the Fundação Carlos Chagas Filho de Amparo à Pesquisa do Estado do Rio de Janeiro (FAPERJ) via the researcher scholarship (E-25/2014) under the program Jovem Cientista do Nosso Estado.

Ameghino, F. (1904). Nuevas Especies de Mamíferos Cretáceos y Terciários de la República Argentina Coni. Anales Soc. Cient. Argentina 58-59, 35-48.

Araújo-Junior, H. I., and Porpino, K. O. (2007). Mamíferos Fósseis da Fazenda Lájea Formosa, São Rafael, Rio Grande do Norte, Brasil: interpretações paleoecológicas. Congr. Ecol. Br. 8, 1-2.

Arruda, D. M., Schaefer, C. E., Fonseca, R. S., Solar, R. R., and Fernandes-Filho, E. I. (2017). Vegetation cover of Brazil in the last $21 \mathrm{ka}$ : new insights into the Amazonian refugia and Pleistocene arc hyphotesis. Glob. Ecol. Biogeogr. 27, 47-56. doi: 10.1111/geb.12646

Ashton, K. G., Tracy, M. C., and Queiroz, A. D. (2000). Is Bergmann's rule valid for mammals. Am. Nat. 156, 390-415. doi: 10.1086/303400

Avilla, L. S., Machado, H., Araújo-Júnior, H. I., Mothé, D., Rotti, A., Nascimento, K. O., et al. (2018). Pleistocene Equus (Equidae: Mammalia) from Northern Brazil: evidence of scavanger behavior by ursids on South American horses. Ameghiniana 55, 517-530. doi: 10.5710/AMGH.05.07.2018.3069

Ayres, M., Ayres-Jr., M., Ayres, D. L., and Santos, A. A. S. (2007). Bioestat: aplicações estatísticas nas áreas das Ciências Biomédicas. Versão 5.0. Belém: Sociedade Civil Mamirauá, MCT-CNPq, 324.

Bacon, C. D., Molnar, P., Antonelli, A., Crawford, A. J., Montes, C., and VallejoPareja, M. C. (2016). Quaternary glaciation and the great American biotic interchange. Geology 44, 375-378. doi: 10.1130/G37624.1

Barron-Ortiz, C. I., Avilla, L. S., Jass, C. N., Bravo-Cuevas, V. M., Machado, H., and Mothé, D. (in press). What is Equus? Reconciling taxonomy and phylogenetic analyses. Front. Ecol. Evol.

Bergmann, C. (1848). Über die Verhältnisse der Wärmeökonomie der Thiere $z u$ ihrer Grösse. Abgedruckt aus den Göttinger Studien 1847. Göttingen: Vandernhoeck and Ruprecht. 
Blackburn, T. M., and Hawkins, B. A. (2004). Bergmanns'rule and the mammal fauna of northen North America. Ecography 27, 715-724. doi: 10.1111/j.0906-7590.2004.03999.x

Boas, J. E. V. (1881). Om en fossil Zebra-Form fra Brasilienes Campos. Med. et Tillaeg om to Arter af Salaegten Hippidion. Det Kongelige Danske Vidensk. Selskabs Skrift. Naturvidensk. Math. Afdeling 1, 305-330.

Borrero, L. A. (2009). "The elusive evidence: the archeological record of the South American extinct megafauna," in American Megafaunal Extinctions at the End of the Pleistocene, ed G. Haynes (New York, NY: Springer), 145-168 doi: 10.1007/978-1-4020-8793-6_8

Boule, M., and Thevenin, A. (1920). Mammifères Fossiles de Tarija. Paris: Imprimerie Nationale, 256.

Branco, W. (1883). Ueber eine fossile Säugethier-Fauna von Puninbei Rio bamba in Ecuador. II: Beschreibung der fauna. Pälaontol. Abhandl. 1, 39-204.

Burmeister, G. (1875). Los Caballos Fósiles de La Pampa Argentina. Buenos Aires: Imprenta "La Tribuna", 88.

Christiansen, P. (2002). Locomotion in terrestrial mammals: the influence of body mass, limb length and bone proportions. Zool. J. Linn. Soc. 136, 685-714. doi: 10.1046/j.1096-3642.2002.00041.x

Costa, T. S. (2017). O Esqueleto Pós-crêniano de Hippidiformes (Equidae: Mammalia) e Aspectos Morfofuncionais e Adaptativos. [Monograph/Bachelor's Monograhp]. Rio de Janeiro: Universidade Veiga de Almeida.

Cuvier, G. (1806). Sur les Elephans vivans et fossiles. Ann. Muséum Natl. d'Hist. Nat. 8, 1-269.

Daniel, H. (1948). Nociones de Geología y Prehistoria de Colombia. Medellín: Bogotá, 360 .

Dantas, M. A. T., Zucon, M. H., and Ribeiro, A. M. (2005). Megafauna pleistocênica da Fazenda Elefante, Gararu, Sergipe, Brasil. Geociências 24:277.

Dias Neto, C. M., Born, P. A., and Chahud, A. (2008). Ocorrência de mamíferos extintos do pleistoceno na localidade de Lagoa da Pedra, município de Igaci, Alagoas. Rev. UnG Geoci. 7, 110-115.

Eisenberg, J. F., and Redford, K. H. (1999). Mammals of the Neotropics, Vol. 3, Ecuador, Bolivia, Brazil. Chicago: University of Chicago Press, 624.

Eisenmann, V., Alberdi, M. T., De Giuli, C., and Staesche, U. (1988). "Collected papers after the "New York International Hipparion Conference, 1981", in Studying Fossil Horses Volume 1. Methodology, eds M. Woodburne, and P. Sondaar (Leiden: E. J. Brill), 72.

Ennen, J. R., Kalis, M. E., Patterson, A. L., Kreiser, B. R., Lovich, J. E., Godwin, J., et al. (2014). Clinal variations or validation of a subspecies? A case study of the Graptemys wigrinoda complex (Testudines: Emydidae). Biol. J. Linn. Soc. 111, 810-822. doi: 10.1111/bij.12234

Faure, M., Guérin, C., and Parenti, F. (1999). Découverte d'une mégafaune holocène à Toca do Serrote do Artur (aire archéologique de São Raimundo Nonato, Piauì, Brésil). Comp. Rendus l'Acad. Sci. IIA Earth Planet. Sci. 329, 443-448. doi: 10.1016/S1251-8050(00)80069-5

França, L. M., Dantas, M. A. T., Zucon, M. H., and Cozzuol, M. A. (2011). Megafauna do Pleistoceno final da Fazenda São José, Poço Redondo, Sergipe, Brasil. Estud. Geol. 21:1.

Frassinetti, D., and Alberdi, M. T. (2001). Los macromamiferos continentals del Pleistoceno Superior de Chile: Reseña historica, localidades, restos fosiles, especies y dataciones conocidas. Estud. Geol. 57, 53-69. doi: 10.3989/egeol.01571-2127

Gervais, H., and Ameghino, F. (1880). Los Mamíferos Fósiles de la América del Sur. Sabih e Igon Paris.

Gervais, P. (1855). Recherches sur lês Mammifères Fossiles de l'Amérique Méridionale. Paris: Chez P. Bertrand, Libraire-Editeur, 63.

Gromova, V. (1949). The history of horses (genus Equus) in the Old World. Tr. Paleontol. Inst. Akad. Nauk SSSR 17, 1-374.

Gromova, V. (1952). Gippariony: (rod Hipparion): po materialam Taraklii, Pavlodara I drugim. Moscow: Izd-vo Akademii nauk SSSR.

Hammer, O. (2012). PAST: Paleontological Statistics, Reference Manual. Oslo: University of Oslo.

Higgins, R. W., and Ruff, C. B. (2011). The effects of distal limb segment shortening on locomotor efficiency in slopped terrain: implications for neandertal locomotor behaviour. Am. J. Phys. Anthropol. 146, 336-345. doi: 10.1002/ajpa.21575

Hildebrand, M. (1987). The mechanics of horse legs. Am. Sci. 75, 594-601.
Hoffstetter, R. (1950). Algunas observaciones sobre los caballos fósiles de America del Sur. Amerhippus gen. nov. Bol. Inform. Cient. Nacional. 3, 426-454.

Hoffstetter, R. (1952). Les Mammifères Pléistocènes de la République de l'Equateur. Mém. Soc. Géol Soc Paris. 31, 1-391.

Hubbe, A. (2008). Contextualização Taxonômica, Tafonômica e Morfométrica dos Remanescentes Ósseos da Gruta Cuvieri (MG), um Sítio Paleontológico do Pleistoceno Tardio. [Thesis/Ph.D.'s thesis]. São Paulo: University of São Paulo.

Kangas, V. M., Rytkönen, S., Kvist, L., Nygrén, T., and Aspi, J. (2016). Geographic cline in the Shape of the moose mandible: indications of an adaptive trend. J. Mammal. Evol. 24, 233-241. doi: 10.1007/s10914-016-9344-y

Katzner, T. E., and Collar, N. J. (2013). Are insular populations of the Philippine falconet (Microhierax erythrogenys) steps in a cline? Condor 115, 575-583. doi: 10.1525/cond.2013.120070

Kerber, L., and Oliveira, E. V. (2008a). Presença de Equus (Perissodactyla, Equidae) e Neuyurus (Cingulata, Glyptodontidae) no Quaternário do município de Quaraí, oeste do Rio Grande do Sul. Cadernos Pes. Série Biol. 20, 18-25.

Kerber, L., and Oliveria, E. V. (2008b). Fósseis da Formação Touro Passo (Pleistoceno Superior), Rio Grande do Sul, Brasil: atualização dos dados e novas contribuições. J. Geosci. 4, 49-64. doi: 10.4013/gaea.20 082.02

Labarca, R. O., and López, P. G. (2006). Los mamiferos finipleistocénicos de la formación quebrada Quereo (IV region - Chile): biogeografia, bioestratigrafia e inferencias paleoambientales. Mastozool. Neotrop. 13, 89-101.

Lister, A. (2018). Darwin's Fossils: Discoveries That Shaped the Theory of Evolution. London: Natural History, 232 pp.

Lund, P. W. (1840). Nouvelles Recherches sur la Faune fossile du Brésil. Ann. Sci. Nat. 13, 310-319.

Lund, P. W. (1846). Letter to Manoel Rodrigues. Lima: Sabará.

MacFadden, B. J. (1994). Fossil Horses: Systematics, Paleobiology, and Evolution of the Family Equidae. Cambridge: Cambridge University Press, 369.

MacFadden, B. J., and Azzaroli, A. (1987). Cranium of Equusinsulatus (Mammalia, Equidae) from the Middle Pleistocene of Tarija, Bolivia. J. Verteb. Paleontol. 7, 325-334. doi: 10.1080/02724634.1987.10011663

MacFadden, B. J., Cerling, T. E., Harris, J. M., and Prado, J. L. (1999). Ancient latitudinal gradients of $\mathrm{C} 3 / \mathrm{C} 4$ grasses interpreted from stable isotopes of New World Pleistocene horse (Equus) teeth. Glob. Ecol. Biogeogr. 8, 137-159 doi: 10.1046/j.1466-822X.1999.00127.x

Machado, H (2018). Revisão Taxonômica do Gênero Equus (Mammalia: Equidae) Extintos da América do Sul. [Dissertation/Master's Thesis]. Rio de Janeiro: National Museum (MN/UFRJ).

Machado, H. (2014). Análise Morfofuncional do Esqueleto Apendicular Distal de Equus, L. 1789 (Equidae: Mammalia) do Pleistoceno Sul-Americano. [Monograph/Bachelor's Monograph]. Rio de Janeiro: Federal University of the State of Rio de Janeiro.

Machado, H., Grillo, O., Scott, E., and Avilla, L. (2018). Following the footsteps of the South American Equus: are autopodia taxonomically informative? $J$. Mammal. Evol. 25, 397-405. doi: 10.1007/s10914-017-9389-6

Mariano, T. F., and Romano, P. S. R. (2017). Intra-specific variation and allometry of the skull of Late Creataceous side-necked turtle Bauruemys elegans (Pleurodira, Podocnemididae) and how to deal with morphometric data in fossil vertebrates. PeerJ 5:e2890. doi: 10.7717/peerj.2890

Mayr, E. (1963a). Animal Species and Evolution. Cambridge: Belknap Press of Harvard University Press, 797.

Mayr, E. (1963b). Species Concepts and Their Application. The Units of Evolution, Cambridge: M. I. T, 15-25.

Mendoza, P. L. (2007). Tafonomía de los mamiferos extintos del Pleistoceno Tardío de la costa meridional del semiárido de Chile (IV region - 32 Latitudes): Alcances culturales y paleoecológicos. Rev. Antropol. Chil. 39, 69-86. doi: 10.4067/S0717-73562007000100005

Moehlman, P. D. (2002). Equids, Zebras and Horses. Status Survey and Conservation Action Plan. IUCN/SSC Equid Specialist Group. Gland: IUCN.

Mothé, D., and Avilla, L. (2015). Mythbusting evolutionary issues on South American Gomphotheriidae (Mammalia: Proboscidea). Q. Sci. Rev. 110, 23-25. doi: 10.1016/j.quascirev.2014.12.013

Newton, I. (1687). Philosophiae Naturalis Principia Mathematica ("Mathematical Principles of Natural Philosophy”), London, 1687; Cambridge, 1713; London, 1726. 
Nogueira, J. S., and Barbosa, O. R. (2015). O paleoambiente da região arqueológica de Central (BA) através dos mamíferos da Toca do Mundinho. Clio Arqueol. 3, 45-66. doi: 10.20891/clio.v30i2p45-66

Nudds, R. L., and Oswald, S. A. (2007). An interspecific test of Allen's rule: evolutionary implications for endothermic species. Evol. 61, 2839-2848. doi: 10.1111/j.1558-5646.2007.00242.x

Orlando, L., Male, D., Alberdi, M. T., Prado, J. L., Prieto, A., Cooper, A., et al. (2008). Ancient DNA clarifies the evolutionary history of american late pleistocene equids. J. Mol. Evol. 66, 533-538. doi: 10.1007/s00239-008-9100-x

Owen, R. (1840). The Zoology of the Voyage of H.M.S. Beagle Under the Command of Captain Fitzroy, R.N., During the Years 1832 to 1836. Part-I - Fossil Mammalia. London: Smith, Elder and Co.

Owen, R. (1845). Descriptive and Illustrated Catalogue of the Fossil Organic Remains of Mammalia and Aves Contained in the Museum of the Royal College of Surgeons of England. London: R and JE Taylor.

Owen, R. (1869). On fossil remains of Equines from Central and South America referable to Equus conversidens, Ow., Equus tau, Ow., and Equus arcidens, Ow. Philos. Trans. R. Soc. Lond. 159, 559-573. doi: 10.1098/rstl.1869.0020

Pereira, J. C., Lopes, R. P., and Kerber, L. (2012). New remains of the late Pleistocene mammals from the Cuí Creek, Southern Brazil. Rev. Bras. Paleontol. 15, 228-239. doi: 10.4072/rbp.2012.2.10

Porpino, K. O., Santos, M. F. C. F., and Bergqvist, L. P. (2004). Registro de Mamíferos Fósseis no Lajedo Soledade, Apodi, Rio Grande do Norte, Brasil. Rev. Bras. Paleontol. 7, 349-358. doi: 10.4072/rbp.2004.3.06

Porta, J. de. (1960). Los équidos de la Sabana de Bogotá. Boletín de Geología. Univ. Ind. Santander 4, 51-78.

Prado, J. L., and Alberdi, M. T. (1994). A quantitative review of the horse genus Equus from South America. Paleontology 37, 458-481.

Prado, J. L., and Alberdi, M. T. (2017). Fossil Horses of South America. Springer International Publishing, 150.

Prado, J. L., Alberdi, M. T., Sánchez, B., and Gómez, G. (2011). The extinction of Equidae and Proboscidea in South America. A test using Carbon isotope data. Estud. Geol. 67, 363-384. doi: 10.3989/egeol.40505.193

Pujos, F., and Salas, R. (2004). A new species of Megatherium (Mammalia: Xenarthra: Megatheriidae) from the Pleistocene of Sacaco and Tres Ventanas, Peru. Paleontology 47, 579-604. doi: 10.1111/j.0031-0239.2004.00376.x

Rancy, A. (1999). "Fossil mammals of the amazon as a portrait of a Pleistocene environment," in Mammals of the Neotropics. The Central Neotropics, Ecuador, Peru, Bolivia, Brazil, Vol. 3, ed K. H. Redford (Chicago, IL: University of Chicago Press), 20-26.

Rasband, W. S. (1997). ImageJ. Bethesda, MD: US National Institutes of Health.

Ray, N., and Adams, J. (2001). A GIS-based vegetation map of the world at the last glacial maximum (25,000-15,000 BP). Internet Archaeol. 11, 1-44. doi: $10.11141 /$ ia.11.2

Recabarren, O. P., Pino, M., and Cid, I. (2011). A new record of Equus (Mammalia: Equidae) from Pleistocene of central-south Chile. Rev. Chil. Hist. Nat. 84, 535-543. doi: 10.4067/S0716-078X2011000400006

Reche, O. (1905). Über eine neue Equidenart aus der Pampasformation. Mitteilungen des Geologischen und Paläontologischen Institutes der Universität Wien 018, 225-241.

Rincón, R., Ascanio, D., Alberdi, M. T., and Prado, J. L. (2006). Nuevo registro de Equus (Amerhippus) santaeelenae (Mammalia, Perissodactyla) delpozo de asfalto de Inciarte (Pleistoceno Superior), estado Zulia, Venezuela. Ameghiniana 43, 529-538.

Román-Carrión, J. L. (2012). Hallazgo de megafauna pleistocénica em en centro histórico de Quito. Rev. Polit. 30,136-146.

Salomon, M. (2001). Evolutionary biogeography and speciation: esay on a synthesis. J. Biogeogr. 28, 13-27. doi: 10.1046/j.1365-2699.2001.00515.x

Salomon, M. (2002). A revised cline theory that can be used for quantified analyses of evolutionary processes without parapatric speciation. J. Biogeogr. 29, 509-517. doi: 10.1046/j.1365-2699.2002.00675.x
Scheffler, S. M., Martins, G. R., Kashimoto, E. M., and Oliveira, A. M. (2010). Revisão sobre a paleontologia no estado do Mato Grosso do Sul: fósseis e afloramentos descritos. Braz. Geogr. J. 1, 65-99.

Sefve, I. (1912). Die fossilen pferde südamerikas. Kungl. Svenska Vetenskapsakad. Handl. 48, 1-185.

Silva, D. D., Sedor, F. A., and Ribeiro, A. M. (2012). Equus (Amerhippus) neogeus Lund, 1840 (Perissodactyla, Equidae) no Quaternário do Estado do Paraná, Brasil. Rev. Bras. Paleontol. 15, 336-344. doi: 10.4072/rbp.2012.3.09

Silva, F. M., Filgueiras, C. F. C., Barreto, A. M. F., and Oliveira, E. V. (2010). Mamíferos do Pleistoceno Superior de Afrânio, Pernambuco, nordeste do Brasil. Q. Environ. Geosci. 2, 1-11. doi: 10.5380/abequa.v2i1-2.14182

Solounias, N., and Semprebon, G. (2002). Advances in the Reconstruction of Ungulate Ecomorphology With Application to Early Fossil Equids. New York, NY: American Museum Novitates, 1-49.

Souza Cunha, F. L. (1971). Sobre os holótipos de Equus (Amerhippus) neogeus Lund, 1840 e Equus (Amerhippus) curvidens Owen, 1844. Anais Acad. Bras. Ciências 43, 619-627.

Spillman, F. (1938). Die fossilen Pferde Ekuadors der Gattung Neohippus. Palaeobiologica 6, 372-393.

Suárez, R., and Santos, G. M. (2015). Cazadores-Recolectores tempranos, supervivência de la fauna de lo pleistoceno (Equus sp y Glyptodon sp.) y tecnologia lítica durante el holoceno temprano em la frontera Uruguay-Brasil. Rev. Arqueol. 23, 20-39. doi: 10.24885/sab. v23i2.298

Symonds, M. R., and Tattersall, G. J. (2010). Geographical variation in bill size across bird species provides evidence for Allen's rule. Am. Nat. 176, 188-197. doi: $10.1086 / 653666$

Wagner, A. (1860). Ueber fossile Säugertierknochen am Chimborasso. Sitzugsberichte der königlich bayerischen Akademie der Wissenschaften zu Müchen, Munich 330-338.

Webb, S. D. (1978). A history of savanna vertebrates in the New World. Part II: South America and the great interchange. Annu. Rev. Ecol. Syst. 9, 393-426. doi: 10.1146/annurev.es.09.110178.002141

Weddel, H. A. (1851). "Voyage dans le Sud de la Bolivie," in Expedition dans les Parties Centrales de l'Amérique du Sud, ed F. de Castelnau (Paris: P. Bertrand), 1-432.

Winge, H. E. (1906). Jordfundne og nuvelende Hoydr (Ungulata) fra Lagoa Santa, Minas Geraes, Brasilien. Med udsigt over gumlernes indbyrdes slaegtskab. Museo Lundii 3, 1-239. doi: 10.5962/bhl.title.15734

Wolf, T. (1875). Geognostische Mittheilungen aus Ecuador. 4: Kritische Zusammenstellung der in Ecuador stattgefundenen Vulkan-Ausbrüche und Erdleben seit der Zeit der Conquista. Neues Jahrbuch Mineral. Geol. Paläeontol. $1875,152-170$.

Woodburne, M. O. (2010). The great American biotic interchange: dispersals, tectonics, climate, sea level and holding pens. Mammal. Evol. 17, 245-264. doi: 10.1007/s10914-010-9144-8

Ximenes, C. L. (2008). “Tanques Fossilíferos de Itapipoca, CE: Bebedouros e cemitérios de megafauna pré-histórica," in Sítios Geológicos e Paleontológicos, eds M. Winge, C. Schobbenhaus, C. R. G. Souza, A. C. S. Fernandes, M. Berbet-Born, E. T. Queiroz (Brasília: CPRM 2), 515.

Conflict of Interest Statement: The authors declare that the research was conducted in the absence of any commercial or financial relationships that could be construed as a potential conflict of interest.

Copyright (c) 2019 Machado and Avilla. This is an open-access article distributed under the terms of the Creative Commons Attribution License (CC BY). The use, distribution or reproduction in other forums is permitted, provided the original author(s) and the copyright owner(s) are credited and that the original publication in this journal is cited, in accordance with accepted academic practice. No use, distribution or reproduction is permitted which does not comply with these terms. 